\title{
Ferrihydrite precipitation in groundwater-fed river systems (Nete and Demer river basins, Belgium): Insights from a combined Fe-Zn-Sr-Nd-Pb- isotope study
}

\author{
V.M. Dekov ${ }^{a},{ }^{*}$, , E. Vanlierde ${ }^{b}$, K. Billström ${ }^{c}$, C.-D. Garbe-Schönberg ${ }^{d}$, D.J. Weiss ${ }^{e}$, G. Gatto Rotondo ${ }^{f}$, \\ K. Van Meel ${ }^{b, f}$, E. Kuzmann ${ }^{g}$, D. Fortin ${ }^{h}$, L. Darchuk $^{\dagger}$, R. Van Grieken ${ }^{\dagger}$
}

a IFREMER, Centre de Brest, Department of Marine Geosciences, 29280 Plouzané, France

b Flanders Hydraulics Research, Ministry of the Flemish Community, Berchemlei 115, B-2140 Borgerhout (Antwerp), Belgium

c Laboratory for Isotope Geology, Swedish Museum of Natural History, Box 50007, SE-104 05 Stockholm, Sweden

${ }^{d}$ Institut fuer Geowissenschaften, Abt. Geologie, Universitaet Kiel, Olshausenstr. 40, D-24118 Kiel, Germany

e Department of Earth Science and Engineering, Imperial College, Prince Consort Road, London SW7 2BP, UK

${ }^{f}$ Department of Chemistry, University of Antwerp, Universiteitsplein 1, B-2610 Antwerpen, Belgium

$g$ Laboratory of Nuclear Chemistry, Hungarian Academy of Sciences Chemical Research Center, Eötvös University, 1/A Pázmány P., Budapest $\mathrm{H}-1117$, Hungary

${ }^{\mathrm{h}}$ Department of Earth Sciences, University of Ottawa, 140 Louis Pasteur, Ottawa, K1N 6 N5, Canada

\author{
*: Corresponding author : V.M. Dekov, tel.: + 33298224953 ; fax: + 33298224570 ; email address : \\ Vesselin.Dekov@ifremer.fr
}

\begin{abstract}
:
Two groundwater-fed river systems (Nete and Demer, Belgium) carry red suspended material that settles on the river bed forming red sediments. The local aquifer that feeds these river systems is a glauconite-rich sand, which provides most of the dissolved Fe to the rivers. The solid component of these systems, i.e., the red suspended material and sediments, has a simple mineralogy (predominantly ferrihydrite), but shows a complex geochemistry pointing out the different processes contributing to the river chemistry: (1) the red sediments have higher transition metal (excluding $\mathrm{Cu}$ ) and detrital element (e.g., $\mathrm{Si}, \mathrm{Al}, \mathrm{K}, \mathrm{Rb}$, etc.) concentrations than the red suspended matter because of their longer residence time in the river and higher contribution of the background (aquifer) component, respectively; (2) the red suspended material and sediments have inherited their rare earth element (REE) patterns from the aquifer; (3) the origin of Sr present in the red suspended matter and red sediments is predominantly marine (i.e., Quaternary calcareous rocks), but a small amount is geogenic (i.e., from detrital rocks); (4) $\mathrm{Pb}$ in both solids originates mostly from anthropogenic and geogenic sources; (5) all of the anthropogenic $\mathrm{Pb}$ in the red suspended material and sediments is hosted by the ferrihydrite; (6) Nd budget of the red riverine samples is controlled by the geogenic source and shows little anthropogenic component; (7) the significant Fe- and $\mathrm{Zn}$-isotope fractionations are in line with the previous studies. Their fractionation patterns do not correlate, suggesting that the processes controlling the isotope geochemistry of $\mathrm{Fe}$ and $\mathrm{Zn}$ are different: oxidation/reduction most likely governs the Fe-isotope fractionation, whereas adsorption/desorption or admixing of anthropogenic sources control the isotope fractionation of $\mathrm{Zn}$.
\end{abstract}




\section{Highlights}

Glauconite dissolution by groundwater supplies $\mathrm{Fe}$ in the Nete and Demer rivers. Red suspension and sediment contain geogenic and seawater derived $\mathrm{Sr}$. $>\mathrm{Pb}$ isotopes indicate a binary mixing involving geogenic and anthropogenic sources.

Keywords : ferrihydrite ; Fe-Zn-Sr-Nd-Pb-isotopes ; Rivers ; Sediments ; suspended matter

\section{Introduction}

Speciation, concentration and mobility of elements in river systems are key factors of the Earth's surface geochemistry and the fate of elements in river systems is an essential part of their global cycles. As a result, the geochemistry of element riverine fluxes (dissolved and suspended) has been studied from different points of view for decades (Meybeck, 2003). Riverine chemistry plays a fundamental role in the oceanic budget and consequently has received particular attention over the last 30 years (Martin and Meybeck, 1979, Milliman and Meade, 1983, Milliman and Syvitski, 1992, Walling and Fang, 2003 and Syvitski et al., 2005).

Recent fundamental essays on riverine geochemistry (Gaillardet et al., 2003 and Meybeck, 2003) concluded that the chemical composition of river systems is extremely variable and depends on a number of factors. Although these studies summarize very large amounts of information on a global scale, our knowledge of river systems with particularly high concentrations of some elements is still limited. For instance, $\mathrm{Fe}$ is a major element in terrestrial rocks, but it is a trace element in rivers. However, in some rivers, Fe dissolved concentrations can be high and lead to the formation of Fe-rich suspended matter which then dominates the riverine suspended load. As a result, the river water takes on a reddish color and its bed is covered by red sediments. Such unusual conditions are found in the Nete and the northern part of the Demer river systems in Belgium. The amount of authigenic Fe-rich 
suspended flux was investigated during recent years and found to represent about $75 \%$ of the total suspended load (Vanlierde et al., 2007), which gives a mean annual authigenic suspended matter yield of $15 \mathrm{t} \cdot \mathrm{km}^{-2} \cdot \mathrm{yr}^{-1}$. This yield is little with respect to the maximum reported values of mean annual suspended matter yield for rivers worldwide $\left(53500 \mathrm{t} \cdot \mathrm{km}^{-2} \cdot \mathrm{yr}^{-}\right.$

1; Walling and Webb, 1996). However, the unusual and poorly constrained composition of these small river systems (Nete and Demer), and the fact that small rivers as sediment suppliers are often overlooked (Milliman and Syvitski, 1992) has led to this study. In view of the potential importance of the particular elemental flux to the ocean from these two river systems, we undertook an investigation of the composition (mineralogy, trace element and isotope geochemistry) and origin of their suspended matter and bed sediments and report our results in this contribution. Our study adds useful information to the global picture that is far from well constrained.

\section{Hydrogeological setting}

The Nete and Demer river basins are located in northeastern Belgium (Fig. 1). The flat topography of the area along with the dense net of little tributaries (creeks, streams) of the main rivers ensure a low erosion rate and minimal detrital flux to the river systems. The groundwater table in the region is high and the rivers are principally groundwater-fed $[62 \%$ $87 \%$ of the total river discharge; summarized by Vanlierde et al. (2007)]. Industrial discharges and sewage treatment contribute varyingly to the different tributaries of these basins [up to $34 \%$ of their total discharge; Vlaamse Milieu Maatschappij (2012) data obtained via http://www.vmm.be/geoview/afvalwater.html]. A thick Neogene sedimentary rock sequence overlain by a thin layer of Quaternary sediments (Fig. 2) composes the relatively simple geological structure of both basins. The Boom Clay Formation is an aquitard, which divides 
the groundwater system into two hydrogeological units (Fig. 2) (cf. Vanlierde et al., 2007). It has been assumed that the groundwater feeding the river systems originates from the upper unit (Vanlierde et al., 2007). This unit comprises three Neogene sandy aquifers: (1) the Merksplas, Brasschaat and Mol Formations; (2) the Lillo, Poederlee and Kasterlee Formations; and (3) the Berchem and Diest Formations (Fig. 2; not all Formations of aquifer 1 are depicted as they are present to the north and east of the cross-section). Aquifers 2 and 3 are glauconite-rich sands. The thick and highly permeable aquifer 3 is the main supplier of groundwater into both river basins. The groundwater in the Neogene aquifers is slightly acid ( $\mathrm{pH}=6.3-6.9)$ and suboxic to anoxic $\left(\left[\mathrm{O}_{2}\right]<1 \mathrm{mg} / \mathrm{L}\right)$ whereas the river water is slightly alkaline $(\mathrm{pH}>7)$ and oxic $\left(\left[\mathrm{O}_{2}\right]=1.22-8.74 \mathrm{mg} / \mathrm{L}\right)$ (Vanlierde et al., 2007; Baken et al., 2013). The average annual suspended flux in the Nete Basin (at the Grobbendonk measurement station of Flanders Hydraulics Research) has been estimated to be 11800 t/yr (1999-2004; Vanlierde et al., 2007). The groundwater is rich in dissolved $\mathrm{Fe}\left(\left[\mathrm{Fe}^{2+}\right]=3.81-58.0 \mathrm{mg} / \mathrm{L}\right.$; Baken et al., 2013), which starts precipitating upon entering the river flow (Fig. 3A) and then flocculating and settling on the river bed (Fig. 3B). Fe-rich precipitates in the river water account for $\sim 75 \%$ of the total suspended matter flux (Vanlierde et al., 2007). The absence of red-color rock units in the drained terrains (Schiltz et al., 1993; Frederickx and Gouwy, 1996) rules out the possibility that the erosion of the substrate may supply red suspended matter to the rivers.

\section{Material and methods}

We studied suspended matter [recovered through centrifugation (8000 rpm for 30 minutes at $18^{\circ} \mathrm{C}$ ) of 10 -litre bulk river water samples collected in plastic buckets] from 3 locations (\#\#1, 2a and 3a) and bed sediment samples (collected with plastic spoons in 200-mL 
plastic bottles) at 7 locations (\#\#2b, 2c, 3b, 4, 5, 6 and 7) (Table 1). Six of the sediment samples were red superficial sediments (hereafter called only red sediments; \#\#2b, 2c, 3b, 4, $6 \mathrm{a}$ and $6 \mathrm{~b}$ ) whereas one was light-grey sediment (\#5) supposed to represent background sedimentation devoided of Fe-rich suspended flux (hereafter called background sediment). Five of the red sediment samples were from the river bed entirely covered with water, whereas the sixth red sediment sample $(\# 2 b)$ was collected from an area of the river where there was very little water flowing, therefore exposing the sediments to air. Additionally, one grayish sand sample from the Diest Formation (i.e., aquifer 3 which likely supplies dissolved Fe to the river systems in the region) and one sample of red precipitate collected at the Pidpa groundwater pumping system (Grobbendonk) were investigated (Table 1). The river water parameters were measured at the sampling sites (in situ) with a YSI 6936 multi-parameter probe (Table 1). All samples (suspended matter and sediments) were freeze dried (at $\mathrm{T}=-$ $32^{\circ} \mathrm{C}$ for 8 hours) prior to any further treatment. After drying, the samples were ground into a fine powder in an agate mortar.

Subsamples $(\sim 0.5 \times 0.5 \mathrm{~cm})$ from all the dried samples (before grinding) were mounted on special sample holders using carbon tape and observed (without any coating) with a scanning electron microscope (SEM) (JSM-6300, V=10 kV, I=12 nA, electron beam diameter of $1 \mu \mathrm{m})$ (University of Antwerp).

Subsamples from each sediment sample were first fixed with a buffered glutaraldehyde solution $(2.5 \%)$ and then dehydrated for 15 minutes in a series of ethanol solutions $(25,50,75$ and $99 \%$, three times) prior to being embedded in LR White resin. The sections were then sectioned on an ultra-microtome and observed by transmission electron microscopy (TEM) using a Philips CM-10 operated at $80 \mathrm{kV}$ (University of Ottawa). Energy dispersive spectroscopy was performed with an EDDAX Sapphire detector that collects spectra over 100 s (live time) with a beam diameter of approximately $200 \mathrm{~nm}$ (University of Ottawa). 
Mineralogical characterization of the suspended matter and sediments was performed by micro-Raman molecular spectroscopy (MRS) (University of Antwerp), X-ray diffractometry (XRD) (University of Sofia) and Mössbauer spectroscopy (Eötvös University). We used a Renishaw InVia micro-Raman spectrometer with a laser excitation at 785 and 514 nm equipped with a Peltier air-cooled CCD detector. A small quantity of the powdered samples was placed on a glass slide on the XYZ-stage of an InVia system, which is a combination of a Leica microscope and a Raman spectrometer. Using a 50x objective lens, spectra from grains of $\sim 2-5 \mu \mathrm{m}$ in size were collected. The number of spectra accumulated varied from 1 to 10 in order to achieve the best signal-to-noise ratio. In some cases, fluorescence caused by the presence of clay in the samples disturbed the Raman signal to such an extent that it was not informative. Mineral identification was performed using a home-built Raman spectral library. For the XRD investigation, we used a Philips X-ray diffractometer PW 1710 with an automatic divergence slit and a monochromatic $\mathrm{Cu} \mathrm{K}_{\alpha}$ radiation at $40 \mathrm{kV}$ and $35 \mathrm{~mA}$. Random powder mounts were scanned from 5 to $80^{\circ} 2 \theta$, with a $0.01^{\circ} 2 \theta$ step, at $2 \mathrm{~s} / \mathrm{step}$. The ${ }^{57} \mathrm{Fe}$ Mössbauer spectra of the powder samples were recorded in transmission geometry with a conventional constant acceleration type Mössbauer spectrometer (WISSEL) at room and liquid nitrogen temperatures. The low-temperature measurements were performed in a temperature controlled Leybold type liquid He flow cryostat at $80 \mathrm{~K} . \mathrm{A}{ }^{57} \mathrm{Co}(\mathrm{Rh})$ source of a $1 * 10^{9} \mathrm{~Bq}$ activity was used and the spectrometer was calibrated with $\alpha$-Fe at room temperature. The spectrum evaluation was carried out with the assumption of Lorentzian line shape using the MOSSWIN code (Klencsár et al., 1996), and the local parameters calculated for the spectral components were isomer shift $(\delta, \mathrm{mm} / \mathrm{s})$, quadrupole splitting $(\Delta, \mathrm{mm} / \mathrm{s})$ and resonant absorption areas (A, \%). These principal parameters obtained from the spectrum provide information on the electron densities at the Mössbauer nuclei (indicating the valence state) and on the magnitude of any electric field 
gradients (indicating molecular symmetry and coordination number of the resonant atom). These local parameters can be used for analytical purposes to identify Fe-bearing minerals in the samples (Kuzmann et al., 1998).

The chemical composition of the samples was determined by X-ray fluorescence (XRF) spectrometry (University of Antwerp) and inductively coupled plasma mass spectrometry (ICP-MS) (University of Kiel). For the XRF analysis, the samples were prepared in the form of thin pressed (manual press, 10 tons for 1 minute) powder pellets. $0.48 \mathrm{~g}$ of cellulose $(\sim 20$ $\mu \mathrm{m}$ powder) was pressed first to be used as a support and a mixture of $0.48 \mathrm{~g}$ of sample and $0.08 \mathrm{~g}$ of cellulose was pressed on top of it. This resulted in an overall pellet thickness of $\sim 1$ $\mathrm{mm}$ and diameter of $3 \mathrm{~cm}$. An Epsilon 5 spectrometer was used for measuring the concentrations of major and some trace elements. Epsilon 5 is a high-energy EDXRF using a polarizing beam with a $600 \mathrm{~W}$ Gd-anode, an exciting voltage ranging from 25 to $100 \mathrm{kV}$ and a current from 0.5 to $24 \mathrm{~mA}$. There were 13 secondary targets $\left(\mathrm{Al}, \mathrm{CaF}_{2}, \mathrm{Ti}, \mathrm{Fe}, \mathrm{Co}, \mathrm{Ge}, \mathrm{KBr}\right.$, $\mathrm{Zr}, \mathrm{Mo}, \mathrm{Ag}, \mathrm{CsI}, \mathrm{CeO}_{2}$ and W) and two barkla-scatterers $\left(\mathrm{Al}_{2} \mathrm{O}_{3}\right.$ and $\left.\mathrm{B}_{4} \mathrm{C}\right)$. The High Purity Ge-detector (HPGe) in this spectrometer has an energy range from 0.7 to $200 \mathrm{keV}$ and a resolution at $\mathrm{Mn} \mathrm{K}_{\alpha}$ of $<165 \mathrm{eV}$. Tube, target, sample and detector are arranged in a Cartesian geometry in order to obtain polarization. The samples were analyzed under vacuum with application of a sample spinner. For the calibration, 17 sediments (river and lake of varying compositions) and soil standard reference materials were used.

The trace and rare earth element composition of the samples was determined by ICPMS using an AGILENT 7500cs instrument. The samples were dissolved by performing a pressurized HF-HCl-HNO ${ }_{3}$-aqua regia attack (Garbe-Schönberg, 1993). The accuracy of the analyses was monitored using the international rock standard GSPN-2. Our values are generally within $<5 \%$ of the recommended values for most elements. The precision of sample duplicates, as well as repeated analyses, was better than $5 \%$ for most elements. 
The chemical preparation for the radiogenic isotope analyses $(\mathrm{Sr}, \mathrm{Nd}, \mathrm{Pb}$ ) of the samples was performed according to standard routines (De Ignacio et al., 2006) in clean laboratory conditions (class 1000 laboratory, class 10 laminar hoods) (Swedish Museum of Natural History). Briefly, approximately $100 \mathrm{mg}$ of powdered samples were loaded in Teflon vials and dissolved with a mixture of concentrated $\mathrm{HF}$ and $\mathrm{HNO}_{3}$ in an oven at $205^{\circ} \mathrm{C}$ for four days. Additional treatment with nitric and hydrochloric acids and subsequent centrifugation were carried out in order to eliminate solid residues. Initial ion exchange was performed in columns filled with $\mathrm{AG} 50 \mathrm{~W} \times 8, \mathrm{H}^{+}$form resin. $\mathrm{Sr}$ was further purified in a second pass through the same columns, whereas Sm and $\mathrm{Nd}$ were separated in Ln-spec columns (Pin and Zalduegui, 1997). The $\mathrm{Pb}$ fractions were redissolved in $\mathrm{HBr}$, and treated further in columns containing $\mathrm{AG} 1 \times 8, \mathrm{Cl}^{-}$form resin. Blank levels are estimated at 300 and $500 \mathrm{pg}$, respectively, for $\mathrm{Nd}$ and $\mathrm{Sr}$ analyses, and $400 \mathrm{pg}$ for $\mathrm{Pb}$ analyses.

A Thermo-Finnigan Triton thermal ionization mass spectrometer (TIMS) was used for the $\mathrm{Sr}$ and $\mathrm{Nd}$ isotope analyses (Swedish Museum of Natural History) and the data were normalized to ${ }^{88} \mathrm{Sr} /{ }^{86} \mathrm{Sr}=0.1194$ and ${ }^{146} \mathrm{Nd} /{ }^{144} \mathrm{Nd}=0.7219$ using an exponential mass fractionation law. Additionally, replicate analyses $(n=10)$ of the NBS987 Sr standard analysed during the course of the study yielded an average ${ }^{87} \mathrm{Sr} /{ }^{86} \mathrm{Sr}$ ratio of $0.710221 \pm 0.000011$ (2 $\sigma$ external precision). Corresponding analyses $(\mathrm{n}=16)$ of the La Jolla $\mathrm{Nd}$ standard yielded an average ${ }^{143} \mathrm{Nd} /{ }^{144} \mathrm{Nd}$ ratio of $0.511848 \pm 0.000009(2 \sigma$ external precision $)$. These standard values are very close to the accepted values, so no additional corrections were applied to the samples' Nd or Sr data.

$\mathrm{Pb}$ isotopic analyses were performed with a Micromass Isoprobe multi-collector ICPMS (MC-ICP-MS) (Swedish Museum of Natural History). For these analyses, $\mathrm{Pb}$ was diluted in $0.5 \mathrm{MHNO}_{3}$ to an estimated concentration of $50 \mathrm{ppb} \mathrm{Pb}$, with $5 \mathrm{ppb} \mathrm{Tl}$ added to allow for an internal correction of mass bias. Measured intensities were corrected for background and 
$\mathrm{Hg}$ interference on mass 204 , and the $\mathrm{Pb}$ isotope ratios of the unknowns were normalized to ${ }^{203} \mathrm{Tl} /{ }^{205} \mathrm{Tl}=0.418918$. We analyzed the NBS981 $\mathrm{Pb}$ standard after every four samples and the external precision (reproducibility) was better than $0.02 \%$, and a conservative estimate of the overall uncertainty for unknowns is $\pm 0.1 \%$ or better.

The chemical preparation of the samples for Fe and $\mathrm{Zn}$ isotope studies was undertaken under clean laboratory conditions (class 1000 laboratory, class 10 laminar hoods) (Imperial College). Fifty milligrams of sample were weighed into $14.7 \mathrm{~mL}$ screw top polytetrafluoroethylene (PTFE) vials. $1 \mathrm{~mL} \mathrm{HF}$ and $0.25 \mathrm{~mL} \mathrm{HNO}_{3}$ were added to the vials and the samples were digested on a hot plate at $150^{\circ} \mathrm{C}$ for 48 hours with daily ultrasonic treatment. After digestion, some solutions still contained small fractions of a solid residue and as a result, $1.5 \mathrm{~mL}$ of aqua regia $\left(2: 1 \mathrm{HCl}: \mathrm{HNO}_{3}\right)$ was added to each vial and left for another 24 hours on the hot plate. Vials were then placed in an ultrasonic bath for 30 minutes (the solutions were clear after this step). All digested samples were evaporated down and then dissolved and refluxed in $\sim 1 \mathrm{~mL} 7 \mathrm{M} \mathrm{HCl}$ and $0.05 \mathrm{~mL} \mathrm{H}_{2} \mathrm{O}_{2}(9 M)$. Solutions were dried down again and re-dissolved in $2.5 \mathrm{~mL} 7 \mathrm{M} \mathrm{HCl}$ containing $0.001 \% \mathrm{H}_{2} \mathrm{O}_{2}$ by volume. Each solution was split in three aliquots: $0.5 \mathrm{~mL}$ for inductively coupled plasma atomic emission spectroscopy (ICP-AES) (made up to $\sim 3.5 \mathrm{~mL} 1 \mathrm{M} \mathrm{HCl}$ prior to concentration measurements), $1 \mathrm{~mL}$ for anion exchange chromatography, and $1 \mathrm{~mL}$ for archive.

A mixed spike with ${ }^{64} \mathrm{Zn}$ and ${ }^{67} \mathrm{Zn}$ was added to the $1-\mathrm{mL}$ aliquots. Zinc and Fe were separated from the matrix using ion exchange chromatography as detailed elsewhere (Chapman et al., 2006). Zinc and Fe fractions were re-dissolved in $0.1 M$ and $0.5 M \mathrm{HNO}_{3}$, respectively, in preparation for the MC-ICP-MS. The isotope measurements were conducted on a HR Nu-Plasma MC-ICP-MS (Imperial College). For the Zn isotopes, a double spike technique was used to correct for mass bias. For Fe, the mass spectrometer was set up in pseudo high resolution in order to resolve for ${ }^{40} \mathrm{Ar}^{14} \mathrm{~N}^{+},{ }^{40} \mathrm{Ar}^{16} \mathrm{O}^{+}$and ${ }^{40} \mathrm{Ar}^{16} \mathrm{OH}^{+}$. The dynamic 
range of the amplifiers was extended from 10 to $20 \mathrm{~V}$ (on $10^{11} \Omega$ resistors), thus improving the signal to amplifier noise ratio and the precision of the higher dynamic range isotopic ratio ${ }^{57} \mathrm{Fe} /{ }^{54} \mathrm{Fe}$. The standard-sample bracketing technique was implemented for mass bias correction. The data acquisition sequence for Fe was the same as that for $\mathrm{Zn}$ : sample, standard and acid blank measurements comprised 25 consecutive five-second integrations. Potential interferences during the $\mathrm{Fe}$ isotope measurements were tested using three isotope plots and the slopes were always consistent with those predicted from the kinetic and equilibrium laws. Isotope ratios are reported in $\delta$-notation where $\delta^{66} \mathrm{Zn}=\left[\left({ }^{66} \mathrm{Zn} /{ }^{64} \mathrm{Zn}\right)_{\text {sample }}\right) /\left({ }^{66} \mathrm{Zn} /{ }^{64} \mathrm{Zn}\right)_{\text {standard }}-$ 1] $x 10^{3}$, and where $\left({ }^{66} \mathrm{Zn} /{ }^{64} \mathrm{Zn}\right)_{\text {sample }}$ is the isotope ratio of the sample and $\left({ }^{66} \mathrm{Zn} /{ }^{64} \mathrm{Zn}\right)_{\text {standard }}$ is the isotope ratio of the standard reference material. Similarly, $\delta^{56} \mathrm{Fe}=$ $\left.\left[\left({ }^{56} \mathrm{Fe} /{ }^{54} \mathrm{Fe}\right)_{\text {sample }}\right) /\left({ }^{56} \mathrm{Fe} /{ }^{54} \mathrm{Fe}\right)_{\text {standard }}-1\right] \times 10^{3}$. All $\delta$-values are reported relative to JMC 30749L for Zn and IRMM-014 for Fe. The accuracy of the isotope measurements was tested by analysis of single element solutions and natural standard reference materials, ensuring that the values corresponded to long-term averages. The standard reference materials and corresponding long-term values were $\delta^{66} \mathrm{Zn}=0.08 \pm 0.04 \%$ (London $\mathrm{Zn}$ ) and $\delta^{66} \mathrm{Zn}=0.25 \pm$ $0.06 \%$ (BCR 027 Blend Ore), $\delta^{56} \mathrm{Fe}=0.44 \pm 0.04 \%$ (Johnson Matthey Fe) and $\delta^{56} \mathrm{Fe}=0.10$ $\pm 0.04 \%$ (Puratronic Alfa Aesar Fe). Errors on the reported $\delta$-values are $\pm 2 \sigma$ calculated from a minimum of three replicate analyses. Procedural blank contributions were typically $20 \mathrm{ng}$ of $\mathrm{Zn}$ and $40 \mathrm{ng}$ of $\mathrm{Fe}$, making the contribution to the sample isotopic composition insignificant.

\section{Results}

\subsection{Mineralogy}


SEM observations revealed that some of the suspended material and red sediment samples were almost entirely composed of hollow tube-like structures $(2 \mu \mathrm{m}$ in diameter, up to $80 \mu \mathrm{m}$ in length) encrusted with Fe-oxyhydroxides (Fig. 4A, B). TEM analyses of unstained thin sections of the same samples showed that the walls of the tube-like structures were composed of aggregated fine particles (Fig. 4C). Similar aggregates were also observed away from the tube-like structures (Fig. 4C). EDS analysis of the tube-like structures (Fig. 4D) revealed the presence of $\mathrm{Fe}$, but also $\mathrm{C}, \mathrm{S}, \mathrm{Si}, \mathrm{P}, \mathrm{O}, \mathrm{Cl}$, and $\mathrm{Ca}$. The other red sediment and suspended matter samples were composed of irregular aggregates (2-10 $\mu \mathrm{m}$ across) of fine Fe-rich particles (results not shown). Their EDS spectra did not differ substantially from those of the tube-like structures.

The Raman spectra of the red sediments showed clear bands at 360, 505 and $710 \mathrm{~cm}^{-1}$ (Fig. 5), which are characteristic of ferrihydrite (Das and Hendry, 2011). The heating caused by the laser beam led to the transformation of ferrihydrite into hematite (with bands at 225, 290, 408, 490 and $607 \mathrm{~cm}^{-1}$; Fig. 5) as previously observed by Mazzetti and Thistlethwaite (2002).

The 293K Mössbauer spectra of all the suspended matter and sediment samples were similar (Table 2; Fig. 6a). The envelope of all the spectra exhibited a pair of lines and no magnetic splitting appeared. All spectra were evaluated as a doublet. The shape of the $80 \mathrm{~K}$ spectra was very similar to the one recorded at $293 \mathrm{~K}$ (Fig. 6b). Since no magnetically split components were present, the $80 \mathrm{~K}$ spectra were also evaluated as a doublet (Table 2). The isomer shift of all doublets was the same (within the experimental error) at both $293 \mathrm{~K}$ $(0.36 \pm 0.01 \mathrm{~mm} / \mathrm{s})$ and $80 \mathrm{~K}(0.47 \pm 0.01 \mathrm{~mm} / \mathrm{s})$. The quadrupole splitting of the doublets slightly varied between $0.74 \pm 0.025 \mathrm{~mm} / \mathrm{s}$ and $0.82 \pm 0.025 \mathrm{~mm} / \mathrm{s}$ at $293 \mathrm{~K}$, and between $0.78 \pm 0.025 \mathrm{~mm} / \mathrm{s}$ and $0.88 \pm 0.025 \mathrm{~mm} / \mathrm{s}$ at $80 \mathrm{~K}$. The Mössbauer parameters clearly revealed that $\mathrm{Fe}$ was in a paramagnetic high spin $\mathrm{Fe}^{3+}$ state in all samples. No $\mathrm{Fe}^{2+}$ was detected. The 
293K Mössbauer parameters of the studied samples were not all in perfect agreement, but they did not significantly deviate from those characteristic of natural Fe-oxides or oxyhydroxides in paramagnetic or superparamagnetic state at room temperature (Stevens et al., 1983; Murad and Johnston, 1987; Murad and Cashion, 2004). Crystalline hematite, magnetite, maghemite, ferroxyhite, bernalite and goethite were not considered since their 293K Mössbauer spectra display magnetic splitting with characteristic hyperfine fields, which is not consistent with our results (Stevens et al., 1983; Kuzmann et al., 1998; Murad and Cashion, 2004). On the other hand, akageneite, lepidocrocite and ferryhydrite have an isomer shift value similar to what we obtained. Since akageneite exhibits a typical magnetically split spectrum at $80 \mathrm{~K}$, the presence of akageneite is not likely because we only observed a doublet. The occurrence of lepidocrocite can also be excluded because its typical value of quadrupole splitting at 293K, $0.53 \mathrm{~mm} / \mathrm{s}$ (Murad and Johnston, 1987), is much less than what we measured. The observed values for isomer shift and quadrupole splitting can therefore be fully assigned to ferrihydrite. The average quadrupole splitting is also in good agreement with that of ferrihydrite which has a 25K magnetic transition temperature (Stevens et al., 1983; Murad and Johnston, 1987; Murad and Cashion, 2004). The slight variation of quadrupole splitting of the different samples (Table 2) likely reflects subtle changes in the structure and composition of ferrihydrite. In summary, the Mössbauer results are in good agreement with the MRS and XRD results which indicated that ferrihydrite was the only Fe-bearing phase in the red suspended matter and red sediment samples (Table 1). The red sediments also contained some quartz (XRD data; Table 1). The light-grey background sediment was mainly composed of quartz whereas the grayish sand from the Diest Formation contained quartz and glauconite (Table 1). The greenish-black electromagnetic fraction of the greyish sand from the Diest Formation was pure glauconite (Table 1). 


\subsection{Geochemistry}

The red riverine suspended matter was on average slightly richer in Fe than the red sediments (mean $\sim 35 \pm 1 \%, 1 \sigma, \mathrm{n}=3$ and $\sim 31 \pm 6 \%, 1 \sigma, \mathrm{n}=6$, respectively; Table 3 ), but contained less $\mathrm{Si}, \mathrm{Al}, \mathrm{Ti}$ and $\mathrm{K}$. It was also enriched in $\mathrm{P}$, whereas the $\mathrm{Mn}, \mathrm{S}, \mathrm{Ca}$ and $\mathrm{Cl}$ contents were similar for both types of samples (Table 3). However, given the variations within each sample type (red suspended matter and red sediment) and the small number of samples these differences must be viewed cautiously. The glauconitic sands from the main aquifer (Diest Formation) and the background sediments contained less $\mathrm{Fe}, \mathrm{Mn}, \mathrm{Ca}, \mathrm{S}, \mathrm{Cl}$ and $\mathrm{P}$, and more $\mathrm{Si}, \mathrm{Al}$ and $\mathrm{Ti}$ than the red suspended matter and red sediments (Table 3 ). The red sediments were richer in most of the trace elements (As, Li, Sc, V, Co, Ni, Zn, Rb, Y, Zr, Cd, $\mathrm{Sb}, \mathrm{Cs}, \mathrm{Ba}, \mathrm{\Sigma REE}, \mathrm{Hf}, \mathrm{Tl}, \mathrm{Pb}, \mathrm{Th}$ and $\mathrm{U})$ than the red suspended matter, but both types of samples had similar concentrations of $\mathrm{Sr}$ and Mo. The background sediments were depleted in $\mathrm{V}, \mathrm{Co}, \mathrm{Ni}, \mathrm{Cu}, \mathrm{Sn}, \mathrm{Mo}, \mathrm{As}$ and $\mathrm{Sb}$, and enriched in $\mathrm{Li}, \mathrm{Nb}, \mathrm{Rb}, \mathrm{Zr}$, Hf and $\mathrm{Tl}$ when compared to the red suspended matter and red sediments (Table 3). These geochemical differences among the red suspended matter, red sediments, background sediment and sand from the Diest Formation are clear on any discriminant diagram that combines several features (Fig. 7): e.g., enrichment in $\mathrm{Fe}$ and depletion in lithogenic elements (those that come with the detrital component) (Fe/Hf ratio), and enrichment in transition elements $\left(\mathrm{Ni}_{\text {sample }} / \mathrm{Ni}_{\text {background sediment }}\right)$. The sand from the Diest Formation (aquifer sand) was the richest in $\mathrm{Li}, \mathrm{Sc}, \mathrm{V}, \mathrm{Cr}, \mathrm{Rb}, \mathrm{Cs}$, ¿REE, Th and $\mathrm{U}$, and the poorest in $\mathrm{Cu}, \mathrm{Cd}$ and $\mathrm{Sn}$ (Table 3).

Chondrite-normalized REE distribution patterns of the suspended matter, red sediments, background sediments and aquifer sands were similar, i.e., they showed a weak positive Ce anomaly, a weak negative Eu anomaly and an enrichment in light REE (Fig. 8A). The red suspended matter and sediments exhibited close values for the $\mathrm{Ce}$ anomaly $(\mathrm{Ce} / \mathrm{Ce} *)$, the $\mathrm{Eu}$ 
anomaly $\left(\mathrm{Eu} / \mathrm{Eu}^{*}\right)$ and the fractionation of light relative to heavy REE $\left(\mathrm{La}_{N} / \mathrm{Lu}_{\mathrm{N}}\right)(\mathrm{Table} 3)$. When normalized to the background sediment (sample \#5), all REE patterns were again similar, but in addition to the weak positive Ce anomaly, they showed a weak positive Eu anomaly as well (Fig. 8B).

The red precipitate collected at the Pidpa groundwater pumping system (sample \# 8, Table 1) had extremely low concentrations of most of the trace elements (mostly below the detection limits; Table 3) and the chondrite-normalized REE distribution pattern was somewhat different from those of the other studied samples (Fig. 8) although it still showed both positive $\mathrm{Ce}$ and negative Eu anomalies.

\section{3. $\mathrm{Sr}$ - $\mathrm{Nd}$-Pb-isotope data}

The $\mathrm{Sr}$ isotope data (Table 4) showed clear differences between the radiogenic "background" samples (\#\# 5 and 7 with ratios of 0.7226-0.7241) and less radiogenic red suspended matter and red sediments. The data for the red suspended matter are quite uniform (0.7097-0.7104) and fall within the broader data range defined by the red sediments $(0.7097-$ 0.7161). The red precipitate collected from the Pidpa underground water pumping system, of which different granules were used in two separate analyses, turned out be isotopically slightly heterogeneous with an average ratio of $\sim 0.7095$. Duplicate analyses of sample \#6a gave similar results, with a difference marginally beyond the internal analytical errors.

The $\mathrm{Pb}$ isotope data (Table 4) show a distribution similar to that observed for the $\mathrm{Sr}$ isotopes: the two background sediment samples possess radiogenic isotope compositions $\left({ }^{206} \mathrm{~Pb} /{ }^{204} \mathrm{~Pb}=18.50-18.53\right)$ whereas the red suspended matter $\left({ }^{206} \mathrm{~Pb} /{ }^{204} \mathrm{~Pb}=18.00-18.15\right)$ and red sediments $\left({ }^{206} \mathrm{~Pb} /{ }^{204} \mathrm{~Pb}=18.00-18.26\right)$ are less radiogenic. The $\mathrm{Pb}$ isotope range of the 
suspended matter overlaps that of the red sediment with the distinction that the latter covers a larger data range.

The Nd isotope data (Table 4) are relatively homogeneous with only minor differences between the different sample types. The background sediments yielded a ${ }^{143} \mathrm{Nd} /{ }^{144} \mathrm{Nd}$ of 0.51203-0.51206 [corresponding $\varepsilon \mathrm{Nd}(0)$ range is from - 11.9 to -11.4 ], whereas the $\mathrm{Nd}$ isotope ratios of the red suspended matter were $0.51205-0.51207$ and $0.51197-0.51211$ for the red sediment. Similarly to the $\mathrm{Sr}$ analysis, the $\mathrm{Nd}$ isotope composition of the Pidpa precipitate could not be reproduced and one of the samples yielded a ${ }^{143} \mathrm{Nd} /{ }^{144} \mathrm{Nd}$ of 0.51215 which is the highest value encountered in this study.

\subsection{Fe-Zn-isotope data}

The proposed Fe source (i.e., greyish sand from Diest Formation; sample \#7) is enriched in the ${ }^{56} \mathrm{Fe}$ isotope (relative to IRMM-014) and has within error, the same isotopic signature $\left(\delta^{56} \mathrm{Fe}=0.42 \pm 0.11 \%\right)$ as the river red suspended matter (samples \#\#1 and 3a), i.e., $0.41 \pm 0.11 \%$ and $0.38 \pm 0.08 \%$, respectively (Table 4). The red sediments (formed after sedimentation of the red suspended matter) show both isotopically lighter $\left(\delta^{56} \mathrm{Fe}=-0.31 \pm\right.$ $0.10 \%$; sample \#2b) and heavier $\left(\delta^{56} \mathrm{Fe}=0.63 \pm 0.05 \%\right.$; sample \#3b) signatures than the $\mathrm{Fe}$ source and Fe-rich suspension.

With respect to the $\mathrm{Zn}$ isotope systematics (Table 4), we find that the source (sample $\# 7$ ) is also enriched in the heavier isotope (relative to JMC 3-0749L) and has a $\delta^{66} \mathrm{Zn}$ signature of $0.34 \pm 0.09 \%$. The river suspended matter is isotopically lighter with $\delta^{66} \mathrm{Zn}$ signatures around zero $(0.02 \pm 0.03$ for sample \#1 and $0.03 \pm 0.07$ for sample \#7). The red sediment has a heavier $\mathrm{Zn}$-isotope composition with $\delta^{66} \mathrm{Zn}$ signatures of $0.14 \pm 0.06$ and $0.40 \pm 0.02 \%$ for samples $\# 2 \mathrm{~b}$ and \#3b, respectively. 


\section{Discussion}

\subsection{Glauconite dissolution as a source of Fe and REE to the river systems}

The Diest Formation, considered to be the main groundwater supplier to the Nete and Demer river systems (Vanlierde et al., 2007), is composed of glauconitic sand (Table 1). Glauconite $\left[\mathrm{K}_{0.6} \mathrm{Na}_{0.05} \mathrm{Fe}^{3+}{ }_{1.3} \mathrm{Mg}_{0.4} \mathrm{Fe}^{2+}{ }_{0.2} \mathrm{Al}_{0.3} \mathrm{Si}_{3.8} \mathrm{O}_{10}(\mathrm{OH})_{2}\right]$ is a Fe-rich dioctahedral clay (illite-smectite mixed-layer) with octahedral $R^{3+}>1.2$ atoms per $\mathrm{O}_{10}(\mathrm{OH})_{2}$, with $\mathrm{Fe}^{3+}>>\mathrm{Al}+$ $\mathrm{Mg}>>\mathrm{Fe}^{2+}$ (Bailey, 1980). It forms in locally reduced environments associated with decaying organic matter within a more oxidizing setting (Hower, 1961), which is commonly encountered at the outer continental shelf-upper continental slope and in saline lakes (Huggett and Cuadros, 2010). Deposition of the Diest Formation took place in the form of sandbanks during a Miocene transgression in a gully that was previously eroded by coast parallel tidal currents (Matthijs, 1999). At low temperatures $\left(\mathrm{T}=25^{\circ} \mathrm{C}\right)$ like those measured in the studied water systems, glauconite is stable at neutral to slightly alkaline $\mathrm{pH}$, but dissolves under acidic and alkaline conditions (Fernandez-Bastero et al., 2008). Under such conditions, the dissolution of glauconite releases $\mathrm{Fe}^{3+}$ and $\mathrm{Fe}^{2+}$, along with other cations $\left(\mathrm{Al}^{3+}, \mathrm{Mg}^{2+}, \mathrm{K}^{+}\right.$, $\mathrm{Na}^{+}$, etc.) from its crystal lattice. Since glauconite is the mineral most vulnerable to water dissolution in the local aquifer (Table 1; sample \#7), its breakdown (dissolution) by the groundwater is likely the major process supplying dissolved Fe to the rivers. This scenario is kinetically reasonable at the $\mathrm{pH}-\mathrm{Eh}-\mathrm{T}$-conditions of the studied water system (FernandezBastero et al., 2008). Given the fact that the river waters (slightly acidic to alkaline; Table 1) have generally inherited their chemical composition from the groundwaters $(\mathrm{pH}=6.3-6.9$; Baken et al., 2013), we assume that the slightly acidic $\mathrm{pH}$ has triggered the dissolution of 
glauconite (the main aquifer-forming mineral, quartz, remains almost intact under these conditions) which leads to the release of Fe into solution. Theoretically, only $\sim 13 \%$ of the total $\mathrm{Fe}$ in glauconite is $\mathrm{Fe}^{2+}$. However, in the local groundwaters $\sim 100 \%$ of the total $\mathrm{Fe}$ is $\mathrm{Fe}^{2+}\left(\left[\mathrm{Fe}^{2+}\right]=3.81-58.0 \mathrm{mg} / \mathrm{L}\right.$; Baken et al., 2013). Given that the local groundwaters are suboxic to anoxic $\left(\left[\mathrm{O}_{2}\right]<1 \mathrm{mg} / \mathrm{L}\right.$; Baken et al., 2013) we suppose that released $\mathrm{Fe}^{3+}$ (major part of the total $\mathrm{Fe}$ in glauconite) is reduced to $\mathrm{Fe}^{2+}$ and becomes mobile until encountering oxic conditions.

The background sediment (sample \#5, Table 1) has a chondrite-normalized REE distribution pattern very similar to that of sedimentary rocks (McLennan, 1989), i.e., it shows an enrichment in light REE, no Ce anomaly and a moderate negative Eu anomaly (Table 3; Fig. 8A). The aquifer sand (\#7) is three times richer in REE than the background sediment (\#5) and its REE distribution pattern differs from that of the background sediment with a pronounced positive Ce anomaly (Table 3; Fig. 8A). Since the principle difference between these two types of sediments is the presence of glauconite in the aquifer sand (Table 1), it is likely that the enrichment in REE and positive Ce anomaly of the aquifer is due to the presence of glauconite. However, previous studies on REE distribution in glauconites (Fleet et al., 1980) have shown that their distribution patterns rarely exhibit significant $\mathrm{Ce}$ anomalies. In addition, recent seafloor glauconites have no or only weak negative Ce anomalies, indicating no significant preferential uptake of Ce (Fleet et al., 1980). However, some glauconites from older sedimentary sequences show small positive Ce anomalies interpreted as being the result of glauconite formation in shallow seas rather than under oceanic conditions (Fleet et al., 1980). Why does the Ce anomaly in glauconites depend on the depth of the seawater? In general, the riverine suspended matter that enters the ocean has REE distribution patterns similar to those of shales and average upper continental crust: enrichment in light REE, no Ce anomaly and a moderate negative Eu anomaly (Condie, 1991). In the 
river-ocean mixing zone, the oxidation of dissolved $\mathrm{Ce}^{3+}$ to $\mathrm{Ce}^{4+}$ and its preferential adsorption onto settling suspended matter results in fractionation of the dissolved REE leading to a distribution pattern characterized by a negative $\mathrm{Ce}$ anomaly $\left(\mathrm{Ce} / \mathrm{Ce}{ }^{*} \sim 0.6\right.$; Dubinin, 2004). This anomaly increases with depth in the water column $(\mathrm{Ce} / \mathrm{Ce} * 0.2$; Dubinin, 2004) as a result of further Ce oxidation and preferential adsorption onto suspended matter (Fe-Mn-oxyhydroxides, clays, etc.). Seawater is the major source of REE to the authigenic minerals (e.g., glauconite) and therefore, the REE $E_{\text {seawater }}$ distribution pattern is one of the major controls on the REE distribution patterns of these minerals. Thus the different $\mathrm{REE}_{\text {seawater }}$ distribution patterns at continental margins $\left(\mathrm{Ce} / \mathrm{Ce}^{*} \sim 0.6\right.$; $)$ and deep ocean $\left(\mathrm{Ce} / \mathrm{Ce}^{*} \sim 0.2\right)$ will result in different REE distribution patterns of authigenic minerals: with no or with positive $\mathrm{Ce}$ anomaly at the continental margins and patterns with negative $\mathrm{Ce}$ anomaly in the deep ocean where the fractionation factor of preferential Ce adsorption is insufficient to create a positive Ce anomaly (Dubinin, 2004). As the Diest Formation was also deposited in shallow seas, this could explain the positive Ce anomaly of the glauconite in it.

Normalization of the REE contents of the samples to the background sediment (almost pure quartz sand; Table 1) REE values will eliminate the influence of the background component. Background sediment-normalized REE pattern of the aquifer sand (Fig. 8B, sample \#7) suggests that the positive Ce anomaly observed at the chondrite-normalized pattern is, indeed due to the presence of glauconite. In addition, glauconite carries a weak positive Eu anomaly. A previous study of an aquifer with mineralogy similar to that of the Diest Formation (major quartz and minor glauconite) showed that the dissolution of glauconite is the major process supplying REE to the groundwater (Bau et al., 2004). Therefore, it is reasonable to assume that the groundwater dissolution of glauconite is the major process supplying not only Fe, but also REE to the river waters of the Nete and Demer systems. As a result of the glauconite dissolution, both positive anomalies ( $\mathrm{Ce}$ and $\mathrm{Eu})$ are 
transferred to the river waters and inherited by the red riverine suspension and ultimately the red sediment (Fig. 8B).

Discussing precisely the sources of REE to the waters of the Nete and Demer rivers we need to keep in mind the technical capabilities of the analytical approach. The detection limits of the major tool for mineralogical analysis we used, the XRD is $\sim 4-5 \%$. Therefore, trace minerals $(<4 \%)$ rich in REE will be XRD-“invisible". We cannot rule out the possible presence of such phases, which theoretically may be appreciable source of REE to the groundwater and may have an impact on the REE distribution patterns.

\subsection{Formation of red suspended matter and red sediment}

Dissolution of glauconite in the aquifer sand (Diest Formation) releases $\mathrm{Fe}^{3+}$ and $\mathrm{Fe}^{2+}$ in the suboxic to anoxic groundwater (see sub-section 5.1). $\mathrm{Fe}^{3+}$ is reduced to $\mathrm{Fe}^{2+}$ and along with the $\mathrm{Fe}^{2+}$ released through the glauconite dissolution enters the river flow, encounters oxidizing conditions (see section 2) and undergoes oxidation, hydrolysis and precipitation. The ultimate oxidation product of the fine red suspended matter in the water and the red sediments is ferrihydrite (based on XRD and Mössbauer spectrosocopy results). Ferrihydrite is a widespread multiphase hydrous ferric oxyhydroxide, which comprises major defect-free crystallites, minor defective crystallites and subordinate ultradisperse hematite (Drits et al., 1993; Manceau, 2009).

The tube-like structures encrusted with Fe-oxyhydroxides (Fig. 4) are reminiscent of the sheaths of Leptothrix spp. (Spring, 2006), a neutrophilic Fe oxidizer. Their presence and abundance suggests that the oxidation of dissolved $\mathrm{Fe}^{2+}$ in the river water is in part microbially mediated, as observed in other studies (Bruun et al., 2010; Gault et al., 2011). On the other hand, the presence of irregular, fine-grained Fe-oxyhydroxide particles away from 
the tube-like structures in the suspension indicates that the oxidation of Fe could also be inorganic since the particles are not in close association with microbial structures. Given the fact that no DNA extractions were performed on the samples, the biogenicity of the Feoxyhydroxides remains circumstantial.

The red precipitate produced during the Fe sequestration from the groundwater in the Pidpa drinking water reservoirs (sample \#8 in Table 1) might be considered as an equivalent of the red riverine sediment. During treatment, the groundwater is aerated and exposed to bacterial cultures without any addition of chemicals. This nearly laboratory equivalent of the red riverine sediment has not been in any prolonged contact with the environment (river system) and has not equilibrated with it. Therefore, it might be considered a riverine sediment equivalent to a sample that has not gained or lost any element due to its equilibration with the environment. As can be seen (Table 3), the Pidpa red precipitate has extremely low concentrations of most of the trace elements. The red riverine suspended matter and sediment have obviously gained a number of trace elements during their residence in the river system (Table 3). Since the trace elements do not precipitate (the water is undersaturated), they are likely adsorbed onto the Fe-oxyhydroxides (ferrihydrite), which are known to have a high sorption capacity. Previous studies (Sholkovitz and Copland, 1981; Warren and Zimmerman, 1994) demonstrated that the adsorption of dissolved trace elements onto riverine suspended matter is a function of a number of variables, including the concentration of organic substances, suspended matter residence time, particle size and surface area, $\mathrm{pH}, \mathrm{Eh}, \mathrm{T}$ and source composition. The pH-Eh-T-conditions at which the red suspended matter and red sediments exist and the source composition are broadly similar (Table 1). Therefore, the amount of adsorbed trace elements in them will mostly depend on the concentration of organic substances, the residence time of the sorbent (ferrihydrite) in the medium (river water) and the particle size and surface area. Since we do not have data on the concentration 
of organic matter in the studied samples, we can only speculate that the higher trace element content in the red sediment than in the red suspended matter (Table 3) might be at least, partly due to the longer residence time of the red sediment in the river water column (i.e., it has had the opportunity to equilibrate with larger water volumes), assuming similar size and surface area of ferrihydrite particles that compose the samples. The red sediment is richer in elements that are associated with the detrital component ( $\mathrm{Si}, \mathrm{Al}, \mathrm{Ti}$ and $\mathrm{K}$ ) than the red suspended matter. Background sediments along with the aquifer sand are however enriched relative to the red suspended matter and red sediments in elements that are commonly attributed to the detrital matter ( $\mathrm{Si}, \mathrm{Al}, \mathrm{Ti}, \mathrm{Nb}, \mathrm{Rb}, \mathrm{Zr}, \mathrm{Hf}, \mathrm{Sc}, \mathrm{Cs}$, Th and $\mathrm{U}$ ) and depleted in transition elements. These relations are clearly visible in Figure 7, which shows the enrichment of Fe normalized to Hf, a conservative "detrital" element representative of background sedimentation, versus the enrichment above background levels of $\mathrm{Ni}$, a transition metal representative of elements adsorbed on $\mathrm{FeOOH}$. Thus, all studied samples fall into three groups: (1) the richest in Fe, i.e. red suspended matter; (2) the richest in adsorbed trace elements, i.e. red sediments; and (3) the poorest in both Fe and trace element, i.e. background sediment and aquifer sand (Diest Formation) (Fig. 7). Obviously, the red sediments and, especially the red suspended matter, are almost devoided of aluminosilicates (Table 3). In other words, the proportion of authigenic component in them strongly dominates over the detrital one. However, we are not sure if this implies a robust authigenic precipitation that "dilutes" the background sedimentation. Instead, the dominance of authigenic component may reflect the very low detrital flux to the river systems caused by the low erosion rates due to the flat topography of the area.

Since the dissolution of glauconite is likely the main process supplying REE to the groundwater (see section 5.1.), we suspect that the REE distribution pattern with a positive Ce anomaly of the aquifer (glauconitic sand sample \#7, Fig. 8) has been inherited from the 
groundwater and transferred to the river waters. Therefore, we infer that the $\mathrm{Fe}$ oxyhydroxides have precipitated in a medium (river water) with a REE pattern similar to that of the aquifer. Precipitation of Fe-oxyhydroxides in acidic solutions leads, in general, to the scavenging of dissolved REE, Ce oxidation and results in REE distribution patterns with a positive Ce anomaly (Bau, 1999). Therefore, the REE patterns with a positive Ce anomaly of the red suspended matter and red sediments (Fig. 8) have likely inherited that of the aquifer with additional imprint of Ce oxidation and accumulation on Fe-oxyhydroxides.

Sediments of the studied rivers contain high and spatially varying $C$ concentrations $(9.4$ - $16 \%$; Baken et al., 2013), which implies possible diagenetic mobilization reactions within the sediments that may involve REE (e.g., Elderfield and Sholkovitz, 1987). The slightly lower positive Ce anomaly of the red sediment than that of the red suspended matter (Table 3; Fig. 8A) might reflect an early diagenetic alteration of the original REE distribution pattern inferred to be inherited from the red suspended matter: initial preferential release of primary Ce from the sediments relative to its REE neighbours due to the organic matter induced reduction of $\mathrm{Ce}^{4+}$ to dissolved $\mathrm{Ce}^{3+}$ (e.g., Elderfield and Sholkovitz, 1987). The negative $\mathrm{Eu}$ anomaly on the chondrite-normalized patterns does not show any substantial variation.

\subsection{Isotopic insights for $\mathrm{Sr}, \mathrm{Nd}$ and $\mathrm{Pb}$ sources}

Strontium and $\mathrm{Pb}$ isotope compositions of the recent background sediment (\#5) and aquifer sand (\#7; Diest Formation representing a pre-industrial deposition) are similar, although significantly more radiogenic than the red suspended matter and red sediments (Table 4). The Upper Miocene Diest Formation underlies the Quaternary thin surface layer in most parts of the region (Fig. 2) and occasionally crops out at the river banks. The main mineralogical difference between it and the background river sediment is the presence of 
glauconite in the former (Table 1). Since the background sediment contains no detectable Fe (Table 3), it is likely that its precursor was the Diest Formation after the dissolution of glauconite (the initially present main Fe-containing phase) under superficial conditions. Glauconite, which may carry significant amounts of Pb, Sr and REE (Jarrar et al., 2000), is an authigenic mineral which starts precipitating in the water column and continues its formation in the sediment (i.e., during the diagenesis). As a result of the chemical exchanges within the sediment matrix, the isotope composition of glauconite mimics that of the matrix. Following this and accepting the hypothesis that the recent background sediment [composed mainly of quartz (Table 1) and, possibly of trace minerals ( $<4 \%$; beyond the "visibility" of mineralogical techniques used) rich in $\mathrm{Pb}, \mathrm{Sr}$ and $\mathrm{REE}]$ is derived from the Diest Formation sand (composed mainly of quartz and glauconite, and trace minerals rich in $\mathrm{Pb}, \mathrm{Sr}$ and $\mathrm{REE}$ ), the noted $\mathrm{Sr}-\mathrm{Nd}-\mathrm{Pb}$-isotopic similarity between the two sediment types can be explained. We propose that the "background" sediments (\#\#5, 7) represent a geogenic, end-member component which is characterized by a ${ }^{206} \mathrm{~Pb} /{ }^{204} \mathrm{~Pb} \geq 18.5\left({ }^{206} \mathrm{~Pb} /{ }^{207} \mathrm{~Pb} \geq 1.185\right), \varepsilon \mathrm{Nd}(0) \sim-$ 11.6, and ${ }^{87} \mathrm{Sr} /{ }^{86} \mathrm{Sr} \sim 0.723$ (Figs 9, 10). Isotope data for sedimentary rocks and sediments from Belgium are limited, but the suggested geogenic end-member compositions appear reasonable as shown by similar (present-day) $\mathrm{Sr}$ isotope compositions for a Devonian sandstone and for Paleogene loess soils from central Belgium (Drouet et al., 2005). Besides, similar (although often somewhat more radiogenic) $\mathrm{Pb}$ isotope data are reported for preindustrial sediments in the Kempen area $(<100 \mathrm{~km}$ NE from the studied area; Sonke et al., 2002) and for sedimentary host rocks (mainly carbonates) of $\mathrm{Zn}-\mathrm{Pb}$ ores (Belgium; Cauet and Weis, 1983).

The red riverine sediments display much less radiogenic $\mathrm{Pb}$ and $\mathrm{Sr}$ compositions compared to the background sediments, which suggests that the Diest Formation is not the only source of these elements adsorbed eventually on ferrihydrite in the rivers. To first order, 
the $\mathrm{Pb}$ isotope compositions of the red riverine sediments (Fig. 10) may result from simple binary mixing involving a geogenic and an anthropogenic source (probably a combination of various contaminants carried by river water). We are not aware of any published $\mathrm{Pb}$-isotope data for river water systems in Belgium, but given the large industrial sector in this country, it is highly likely that such waters are strongly influenced by atmospheric input involving different anthropogenic sources. Many studies have focused on $\mathrm{Pb}$ isotopes as a proxy for understanding the anthropogenic influence on the environment (e.g., Bollhöfer and Rosman, 2001; De Vleeschouwer et al., 2007). Quite often, such data form crude linear arrays consistent with a simple binary mixing. Our study also shows a similar trend (the best-fit line in Fig. 10). We have used various reference data for comparison (Fig. 10), but it must be noted that the anthropogenic source (Benelux and Germany modern aerosols) represents a mixture of several components (such as mine waste and emissions from the steel and coal plants), and it is not possible to constrain their relevance and exact isotopic nature in the study area. Soot from diesel and gasoline car exhausts are isotopically very variable and have been used along with data from incinerators and steel plants in Germany, France and Switzerland to define a European industrial $\mathrm{Pb}$ line (Haack et al., 2002), which has a similar trend to the modern aerosol field, but extends towards more elevated ${ }^{206} \mathrm{~Pb} /{ }^{207} \mathrm{~Pb}$ ratios. The red riverine suspended matter and sediment plot mainly in an area between the generalized field for modern aerosols (affecting Germany and Benelux) and the background sediments (Fig. 10). Belgian $\mathrm{Zn}-\mathrm{Pb}$ ores (south of the study area; their mining and processing ended in the 1940s) can be ruled out as a substantial contributor of $\mathrm{Pb}$ in the rivers because their $\mathrm{Pb}$ data are displaced away from the linear array (Fig. 10) and they are too radiogenic (the average ${ }^{206} \mathrm{~Pb} /{ }^{204} \mathrm{~Pb}$ is close to 18.4 for the major ores) to account for the range observed in the riverine sediment data. 
The $\mathrm{Pb}-\mathrm{Pb}$ isotopic system shows that the red riverine suspended matter and red sediments are affected by anthropogenic pollution in the river. However, it is hard to quantify the relative contribution of the geogenic and anthropogenic source(s) as the $\mathrm{Pb}$ contents of the end-members and the ability of ferrihydrite to adsorb $\mathrm{Pb}$ at the ambient conditions are not well constrained. Furthermore, it cannot be ruled out that some minor $\mathrm{Pb}$ leached from a local marine carbonate source also exerts some control on the measured $\mathrm{Pb}$ isotope compositions. However, given that the ferrihydrite-bearing suspension and sediments partly plot within the field of modern aerosols (Fig. 10) it is likely that the anthropogenic end-member source dominates. Furthermore, it seems possible that the relative importance of industrial and urban pollutants differs given the range of measured $\mathrm{Pb}$ isotope compositions for the riverine samples from different localities and also indicated by their spread in $\mathrm{Pb}$ concentrations (3.820.7 ppm; Table 3).

With respect to the observed $\mathrm{Sr}$ isotope relationships, a mixing model needs to be considered. It has been found that the river water from two localities in central and southern Belgium (Drouet et al., 2005) shows a Sr isotope composition close to that of North Atlantic seawater: 0.7092 (Piepgras and Wasserburg, 1980). Since one artificial red precipitate (\#8a) showed Sr isotope signature close to that of the North Atlantic seawater, it seems likely that there is a modern seawater contribution to the total Sr-budget in the Belgian river systems. It is known that certain Quaternary rock formations that overlay the Diest Formation are partly calciferous and contain shells and microfossils (Schiltz et al., 1993). If $\mathrm{Sr}$ from such strata is leached and locally added to the studied river systems, this would result in a Sr signature approaching that of modern, marine Sr. A direct seawater Sr contribution through sea salt spray seems less likely given that the $\mathrm{Cl}$ contents in the samples with ${ }^{87} \mathrm{Sr} /{ }^{86} \mathrm{Sr} \sim 0.7092$ are not enhanced (Table 3). A more radiogenic second source of $\mathrm{Sr}$ also needs to be considered and (as discussed earlier) the Diest Formation sand $\left(\# 7 ;{ }^{87} \mathrm{Sr} /{ }^{86} \mathrm{Sr}=0.7226\right)$, being the 
precursor to the recent background sediment (\#5), is a good approximation of a local geogenic component. To further constrain the involved mixing components we used a plot of the $\mathrm{Sr}$ isotope composition versus the $\mathrm{Al} / \mathrm{Fe}$ ratio (Fig. $11 \mathrm{~A}$ ). Basically, all red riverine suspended matter and sediments cluster close to the marine $\mathrm{Sr}$ isotope value, but along a binary mixing trend between the two inferred end-components: marine and geogenic (Fig. $11 \mathrm{~A}$ ). In order to evaluate the mixing proportions of these two end-components we used a diagram of $\mathrm{Sr}$ content versus $\mathrm{Sr}$ isotope composition (Fig. $11 \mathrm{~B}$ ). Such binary mixing estimates that are based on standard binary mixing equations (e.g., Faure and Mensing, 2005) are somewhat speculative given that they are sensitive to the chosen parameters for the end-components. Whereas, reasonable numbers for both the Sr concentration and isotope composition of the geogenic component (Diest Formation sand), and the $\mathrm{Sr}$ isotope composition of the marine component are known, the $\mathrm{Sr}$ concentration of the latter is unknown. The reason for the apparent distribution of the data along different tentative mixing hyperbolae (Fig. 11 B) may be that the marine $(\mathrm{M})$ end-component has different $\mathrm{Sr}$ concentrations in different parts of the river system. We have selected two samples to illustrate two hypothetical mixing scenarios that basically differ in the $\mathrm{Sr}$ content of the inferred marine source: $\mathrm{M}_{1}$ with $[\mathrm{Sr}]=200 \mathrm{ppm}$ and $\mathrm{M}_{2}$ with $[\mathrm{Sr}]=60 \mathrm{ppm}$. Sample \#2a with a low Al/Fe ratio (0.004; as expected for a predominant non-detrital source) plots furthest away from the tentative geogenic source in the $\mathrm{Pb}$ isotope diagram (Fig. 10). This sample is arbitrarily used to characterize the average (A) $\mathrm{Sr}$ component transported in the river system (Fig. $\left.11 \mathrm{~B} ;{ }^{87} \mathrm{Sr} /{ }^{86} \mathrm{Sr}=0.7100,[\mathrm{Sr}]=50 \mathrm{ppm}\right)$. The Sr isotope composition of \#2a falls close to the G-M $\mathrm{M}_{2}$ mixing hyperbola, which indicates $\sim 10$ \% geogenic (G) contribution (Fig. 11 B). Samples \#\#1, 2c, 4, 6a, 6b contain $~ 20-30 \%$ geogenic Sr. On the other hand, sample \#2b deviates markedly from the sample cluster around A with a more radiogenic $\mathrm{Sr}\left({ }^{87} \mathrm{Sr} /{ }^{86} \mathrm{Sr}=0.7161\right)$. It tentatively plots on a $\mathrm{G}-\mathrm{M}_{1}$ mixing hyperbola suggesting an involvement of $\sim 90 \%$ of geogenic component. The reason why 
samples \#\#3a and $3 \mathrm{~b}$ are characterized by a $\mathrm{Sr}$ isotope signature less radiogenic than the $\mathrm{A}$ composition may simply be due to the incorporation of a large proportion of a marine component rich in $\mathrm{Sr}$. The observation that $\mathrm{Pb}$ - and Sr-isotope composition of the red sediments tend to be more variable and have slightly higher Al contents when compared to the red suspended matter is probably largely due to the presence of a slightly larger nonauthigenic (detrital) component in the former sample types (Table 1).

The red riverine suspended matter shows uniform $\mathrm{Nd}$ isotope data [average $\varepsilon \mathrm{Nd}(0) \sim-$ 11.3] very similar to those of the two background sediments (\#\#5 and 7). Analogous to the $\mathrm{Sr}$ and $\mathrm{Pb}$ systems, the $\mathrm{Nd}$ isotopic variation of the red riverine sediments is larger and it encompasses the data of the other sample types. The main reason for this isotopic overlap is probably due to the aquifer sample (\#7, sand from the Diest Formation) controlling the $\mathrm{Nd}$ budget of the red riverine samples. This geogenic source is enriched in REE ( $\Sigma \mathrm{REE}=111$ ppm; Table 3) compared to the riverine suspended matter and sediment. The REE are probably mainly associated with glauconite (and perhaps with some trace minerals; $<4 \%$ of the source rock) and therefore readily released into ground water and consequently into river water after the break-down of this mineral. In addition, a hypothetical average $\mathrm{Nd}$ isotopic signature of potential anthropogenic sources (cf. Geagea et al., 2008), which among themselves may show a considerable isotopic variation (Fig. 9), may not differ that much from the geogenic component controlling the isotopic signature of uncontaminated river water (i.e., local groundwater).

\subsection{Some features of $\mathrm{Fe}$ and $\mathrm{Zn}$ isotope systematics in the studied rivers}

The limited number of samples analyzed for Fe and $\mathrm{Zn}$ isotopes (Table 4) limits the insights that can be gained into the Fe-Zn-isotope systematics of the river systems. 
Specifically, the isotope composition of dissolved $\mathrm{Fe}$ and $\mathrm{Zn}$ in the groundwater and river water are unknown, making it difficult to draw connections between the isotope pools of the aquifer sand, suspended matter and sediments. Therefore, any interpretations of the scant data remain speculative.

The complexity of Fe-isotope fractionation in interconnected Earth surface systems such as ours, i.e., rock, groundwaters, surface waters, river suspended matter and sediments, has been the subject of several recent studies (Fantle and DePaolo, 2004; Teutsch et al., 2005; Bergquist and Boyle, 2006; Ingri et al., 2006; de Jong et al., 2007; Rouxel et al., 2008; Escoube et al., 2009). Fe-isotope composition of the Diest Formation sand $\left(\delta^{56} \mathrm{Fe}=0.42 \%\right.$; Table 4) like that of clastic sedimentary rocks $\left(\delta^{56} \mathrm{Fe}=0.11 \%\right.$; Beard et al., 2003) is heavier than that of the bulk silicate Earth $\left(\delta^{56} \mathrm{Fe}_{\text {bulk continental crust }}=0.07 \%, \delta^{56} \mathrm{Fe}_{\text {upper continental crust }}=\right.$ $0.08 \%$ o, $\delta^{56} \mathrm{Fe}_{\text {mean mafic Earth }}=0.07 \%$; all relative to IRMM-014; Poitrasson, 2006). Fe-isotope fractionation in the river systems is inferred to be mainly controlled by two processes: oxidation of $\mathrm{Fe}^{2+}$ to $\mathrm{Fe}^{3+}$ and adsorption of $\mathrm{Fe}^{2+}$ onto $\mathrm{Fe}^{3+}$-oxyhydroxides (Bullen et al., 2001; Welch et al., 2003; Croal et al., 2004; Teutsch et al., 2005; Balci et al., 2006; Chan et al., 2006; Busigny and Dauphas, 2007; Wu et al., 2011). The ranges of $\delta^{56} \mathrm{Fe}$ in the red suspended matter and red sediments measured during this study (Table 4) are in line with previous investigations of river systems. Therefore, we may assume that the Fe-isotope signatures of the studied suspension and sediments are likely controlled by the same processes: $\mathrm{Fe}^{2+}$ oxidation and adsorption.

The patterns of isotope fractionation between the different reservoirs (source rock suspended matter - sediment) are different for $\mathrm{Fe}$ and $\mathrm{Zn}$, suggesting that the underlying geochemical controls are different.

$\delta^{66} \mathrm{Zn}$ of the Diest Formation sand $(0.34 \%$; Table 4$)$ is within the range observed for sedimentary rocks (Pons et al., 2011). $\delta^{66} \mathrm{Zn}$ values in the red suspended matter and red 
sediments (Table 4) are similar to those of the riverine suspension and sediments measured in previous studies (Chen et al., 2008, 2009; Peel et al., 2009; Pons et al., 2011). The lighter $\delta^{66} \mathrm{Zn}$ of the red suspended matter relative to the source rock (Diest Formation sand, Table 4) is likely explained by the preferential release of ${ }^{64} \mathrm{Zn}$ in the groundwater during alteration of the source rock (e.g., Weiss et al., 2014) and/or ${ }^{64} \mathrm{Zn}$ release into the river water from industrial sources (e.g., Weiss et al., 2007; Chen et al., 2008) and subsequent Zn adsorption on the suspended particles. Detrital material $\left(\delta^{66} \mathrm{Zn}_{\text {Diest Formation sand }}=0.34 \%\right.$ o $)$ does not dominate the $\mathrm{Zn}$ budget of the red sediments $(4.7-24.2 \%$ of the total, calculated using the $\mathrm{Si}$ content; Table 3) suggesting that an additional source of heavy $\mathrm{Zn}$ or/and an additional fractionation process is needed to account for the heavier $\mathrm{Zn}$-isotope values of the red sediments relative to the red suspended matter (Table 4).

\section{Conclusions}

Our study showed that the dissolution of specific minerals in an aquifer supplies a number of elements to the surface run-off and exerts a major control on river chemistry. Iron, Sr, REE and possibly other elements with similar behavior are mostly provided by groundwater to the studied rivers. Most of the $\mathrm{Pb}$ and possibly $\mathrm{Zn}$ enter the river through anthropogenic activities. Oxidation of $\mathrm{Fe}$ in the river and precipitation of ferrihydrite are processes that further act as a natural chemical filter. Ferrihydrite, a mineral with high sorption capacity, scavenges a number of elements from the river water and settles on the river bed, thus immobilizing them. This mechanism is capable of naturally sequestering heavy metals and nutrients released in the river through industrial and agricultural activities and of cleaning the river water. Therefore, in order to improve our knowledge of river chemistry and develop strategies for river water remediation, further studies are necessary on nutrient 
concentrations of the red suspension and red sediments and laboratory experiments are needed with artificial injection of dissolved Fe into polluted river waters.

\section{Acknowledgements}

We thank Flanders Hydraulics Research (Antwerp, Belgium) for funding our sampling campaign and for support in the use of their field and sedimentology laboratory facilities. We also thank Pidpa (Antwerp, Belgium) for providing the Fe-oxyhydroxide precipitate sample from their facility at WPC Grobbendonk. An anonymous reviewer, S. Krishnaswami and especially the handling editor, L. Reisberg, are thanked for their comments and professional handling of the manuscript.

\section{References}

Bailey, S.W., 1980. Summary of recommendations of AIPEA nomenclature committee. Clay Clay Miner. 28, 73-78.

Baken, S., Sjöstedt, C., Gustafsson, J.P., Seuntjens, P., Desmet, N., De Schutter, J., Smolders, E., 2013. Characterization of hydrous ferric oxides derived from iron-rich groundwaters and their contribution to the suspended sediment of streams. Appl. Geochem. 39, 59-68.

Balci, N., Bullen, T.D., Witte-Lien, K., Shanks, W.C., Motelica, M., Mandernack, K.W., 2006. Iron isotope fractionation during microbially stimulated Fe(II) oxidation and Fe(III) precipitation. Geochim. Cosmochim. Acta 70, 622-639.

Bau, M., 1999. Scavenging of dissolved yttrium and rare earths by precipitating iron oxyhydroxide: Experimental evidence for Ce oxidation, Y-Ho fractionation, and lanthanide tetrad effect. Geochim. Cosmochim. Acta 63, 67-77. 
Bau, M., Alexander, B., Chesley, J.T., Dulski, P., Brantley, S.L., 2004. Mineral dissolution in the Cape Cod aquifer, Massachusetts, USA: I. Reaction stoichiometry and impact of accessory feldspar and glauconite on strontium isotopes, solute concentrations, and REY distribution. Geochim. Cosmochim. Acta 68, 1199-1216.

Beard, B.L., Johnson, C.M., Von Damm, K.L., Poulson, R.L., 2003. Iron isotope constraints on Fe cycling and mass balance in oxygenated Earth oceans. Geology 31, 629-632.

Bergquist, B., Boyle, E.A., 2006. Iron isotopes in the Amazon River system: Weathering and transport signatures. Earth Planet. Sci. Lett. 248, 54-68.

Bollhöfer, A., Rosman, K.J.R., 2001. Lead isotopic ratios in European atmospheric aerosols. Phys. Chem. Earth $26,835-838$.

Bruun, A.-M., Finster, K., Gunnlaugsson, H.P., Nørnberg, P., Friedrich, M.W., 2010. A comprehensive investigation on iron cycling in a freshwater seep including microscopy, cultivation and molecular community analysis. Geomicrobiol. J. 27, 15-34.

Bullen, T.D., White, A.F., Childs, C.W., Vivit, D.V., Schulz, M.S., 2001. Demonstration of significant abiotic iron isotope fractionation in nature. Geology 29, 699-702.

Busigny, V., Dauphas, N., 2007. Tracing paleofluid circulations using iron isotopes: A study of hematite and goethite concretions from the Navajo Sandstone (Utah, USA). Earth Planet. Sci. Lett. 254, 272-287.

Cauet, S., Weis, D., 1983. Lead isotope study of lead-zinc mineralization and its host sediments, Heure, Belgium: basis for a genetic model. Econ. Geol. 78, 1011-1016.

Cauet, S., Weis, D., Herbosch, A., 1982. Genetic study of Belgian lead zinc mineralization in carbonate environments through lead isotopic geochemistry. Bull. BRGM II 4, 329-341.

Chan, M.A., Johnson, C.M., Beard, B.L., Bowman, J.R., Parry, W.T., 2006. Iron isotopes constrain the pathways and formation mechanisms of terrestrial oxide concretions: A tool for tracing iron cycling on Mars. Geosphere 2, 324-332.

Chapman, J., Mason, T.F.D., Weiss, D.J., Coles, B.J., Wilkinson, J.J., 2006. Chemical separation and isotopic variations of $\mathrm{Cu}$ and $\mathrm{Zn}$ from five geological reference material. Geostand. Geoanal. Res. 30, 5-16.

Chen, J., Gaillardet, J., Louvat, P., 2008. Zinc isotopes in the Seine river waters, France: a probe of anthropogenic contamination. Environ. Sci. Technol. 42, 6494-6501.

Chen, J., Gaillardet, J., Louvat, P., Huon, S., 2009. Zn isotopes in the suspended load of the Seine River, France: Isotopic variations and source determination. Geochim. Cosmochim. Acta 73, 4060-4076. 
Cocherieab, A., Negrela, P., Royac, S., Guerrota, C., 1998. Direct determination of lead isotope ratios in rainwater using inductively coupled plasma mass spectrometry. J. Anal. At. Spectrom. 13, 1069-1073.

Condie, K.C., 1991. Another look at rare earth elements in shales. Geochim. Cosmochim. Acta 55, $2527-2531$.

Croal, L.R., Johnson, C.M., Beard, B.L., Newman, D.K., 2004. Iron isotope fractionation by Fe(II)-oxidizing photoautotrophic bacteria. Geochim. Cosmochim. Acta 68, 1227-1242.

Das, S., Hendry, M.J., 2011. Application of Raman spectroscopy to identify iron minerals commonly found in mine wastes. Chem. Geol. 290, 101-108.

De Ignacio, C., Munoz, M., Sagredo, J., Fernandez-Santin, S., Johansson, A., 2006. Isotope geochemistry and FOZO mantle component of the alkaline-carbonatitic association of Fuerteventura, Canary Islands, Spain. Chem. Geol. 232, 99-113.

de Jong, J., Schoemann, V., Tison, J.-L., Becquevort, S., Masson, F., Lannuzel, D., Petit, J., Chou, L., Weis, D., Mattielli, N., 2007. Precise measurement of Fe isotopes in marine samples by multi-collector inductively coupled plasma mass spectrometry (MC-ICP-MS). Anal. Chim. Acta 589, 105-119.

Dejonghe, L., 1998. Zinc-lead deposits of Belgium. Ore Geol. Rev. 12, 329-354.

De Vleeschouwer, F., Gérard, L., Goormaghtigh, C., Mattielli, N., Le Roux, G., Fagel, N., 2007. Atmospheric lead and heavy metal pollution records from a Belgian peat bog spanning the last two millenia: Human impact on a regional to global scale. Sci. Total Environ. 377, 282-295.

Drits, V.A., Sakharov, B.A., Salyn, A.L., Manceau, A., 1993. Structural model for ferrihydrite. Clay Miner. 28, 185-208.

Drouet, Th., Herbauts, J., Gruber, W., Demaiffe, D., 2005. Strontium isotope composition as a tracer of calcium sources in two forest ecosystems in Belgium. Geoderma 126, 203-223.

Dubinin, A.V., 2004. Geochemistry of rare earth elements in the ocean. Lithol. Miner. Resour. 39, $289-307$.

Elderfield, H., Sholkovitz, E.R., 1987. Rare earth elements in the pore waters of reducing nearshore sediments. Earth Planet. Sci. Lett. 82, 280-288.

Escoube, R., Rouxel, O.J., Sholkovitz, E., Donard, O.F.X., 2009. Iron isotope systematics in estuaries: The case of North River, Massachusetts (USA). Geochim. Cosmochim. Acta 73, 4045-4059.

Fantle, M.S., DePaolo, D.J., 2004. Iron isotopic fractionation during continental weathering. Earth Planet. Sci. Lett. 228, 547-562.

Faure, G., Mensing, T.M., 2005. Isotopes - Principles and Applications. $3^{\text {rd }}$ edition. John Wiley \& Sons, 897 pp. 
Fernandez-Bastero, S., Gil-Lozano, C., Briones, M.J.I., Gago-Duport, L., 2008. Kinetic and structural constraints during glauconite dissolution: implications for mineral disposal of $\mathrm{CO}_{2}$. Mineral. Mag. 72, 27-31.

Fleet, A.J., Buckley, H.A., Johnson, L.R., 1980. The rare earth element geochemistry of glauconites and celadonites. J. Geol. Soc. London 137, 683-688.

Frederickx, E., Gouwy, S., 1996. Toelichting bij de Quartair geologische kaart, Kaartblad 25, Hasselt, Vlaamse Overheid, Departement Leefmilieu, Natuur en Energie, pp. 54.

Gaillardet, J., Viers, J., Dupré, B., 2003. Trace elements in river waters. In: Drever, J.I. (Ed.), Geochemistry of Earth Surface Systems. Elsevier, Amsterdam. Treatise on Geochemistry 5, pp. 225-272.

Garbe-Schönberg, C.-D., 1993. Simultaneous determination of thirty seven trace elements in twenty eight international rock standards by ICP-MS. Geostandard Newslett. 17, 81-97.

Gault, A.G., Ibrahim, A., Langley, S., Renaud, R., Takahashi, Y., Boothman, C., Lloyd, J.R., Clark, I.D., Ferris, F.G., Fortin, D., 2011. Microbial and geochemical features suggest iron redox cycling within bacteriogenic iron oxide-rich sediments. Chem. Geol. 281, 41-51.

Geagea, M.L., Stille, P., Gauthier-Lafaye, F., Millet, M., 2008a. Tracing of industrial aerosol sources in an urban environment using $\mathrm{Pb}, \mathrm{Sr}$ and $\mathrm{Nd}$ isotopes. Environ. Sci. Technol. 42, 692-698.

Geagea, M.L., Stille, P., Gauthier-Lafaye, F., Perrone, Th., Aubert, D., 2008b. Baseline determination of the atmospheric $\mathrm{Pb}, \mathrm{Sr}$ and $\mathrm{Nd}$ isotopic compositions in the Rhine valley, Vosges mountains (France) and the Central Swiss Alps. Appl. Geochem. 23, 1703-1714.

Haack, U.K., Gutsche, F.H., Plessow, K., Heinrichs, H., 2002. On the isotopic composition of Pb in cloudwaters in central Germany: a source discrimination study. Water Air Soil Poll. 139, 261-288.

Hissler, C., Stille, P., Krein, A., Geagea, M.L., Perrone, T., Probst, J.-L., Hoffmann, L., 2008. Identifying the origins of local atmospheric deposition in the steel industry basin of Luxembourg using the chemical and isotopic composition of the lichen Xanthoria parietina. Sci. Total Environ. 405, 338-344.

Hofmann, A.W., 1997. Mantle geochemistry: the message from oceanic volcanism. Nature 385, 219-228.

Hower, J., 1961. Some factors concerning the nature and origin of glauconite. Am. Mineral. 46, 313-334.

Huggett, J.M., Cuadros, J., 2010. Glauconite formation in lacustrine/palaeosol sediments, Isle of Wight (Hampshire Basin), UK. Clay Miner. 45, 35-49.

Ingri, J., Malinovsky, D., Rodushkin, I., Baxter, D.C., Widerlund, A., Andersson, P., Gustafsson, Ö., Forsling, W., Öhlander, B., 2006. Iron isotope fractionation in river colloidal matter. Earth Planet. Sci. Lett. 245, 792789. 
Jarrar, G., Amireh, B., Zachmann, D., 2000. The major, trace and rare earth element geochemistry of glauconites from the early Cretaceous Kurnub Group of Jordan. Geochem. J. 34, 207-222.

Klencsár, Z., Kuzmann, E., Vértes, A., 1996. User-friendly software for Mössbauer spectrum analysis. J. Radioanal. Nucl. Chem. 210, 105-118.

Kuzmann, E., Nagy, S., Vértes, A., Weiszburg, T., Garg, V.K., 1998. Geological and mineralogical applications of Mössbauer spectroscopy. In: Vértes, A., Nagy, S., Süvegh, K. (Eds.), Nuclear Methods in Mineralogy and Geology, Techniques and Applications. Plenum Press, N.Y. pp. 285-376.

Manceau, A., 2009. Evaluation of the structural model for ferrihydrite derived from real-space modeling of highenergy X-ray diffraction data. Clay Miner. 44, 19-34.

Martin, J.-M., Meybeck, M., 1979. Elemental mass-balance of material carried by major world rivers. Mar. Chem. 7, 173-206.

Matthijs, J., 1999. Kaartblad 25 Hasselt. Toelichtingen bij de Geologische kaart van België - Vlaams Gewest. Belgisch Geologische Dienst en Afdeling Natuurlijke Rijkdommen en Energie, Brussel. pp. 104.

Mazzetti, L., Thistlethwaite, P.J., 2002. Raman spectra and thermal transformations of ferrihydrite and schwertmannite. J. Raman Spectrosc. 33, 104-111.

McArthur, J.M., Howarth, R.J., Bailey, T.R., 2001. Strontium isotope stratigraphy: LOWESS version 3: Best fit to the marine Sr-isotope curve for 0-509 Ma and accompanying look-up table for deriving numerical age. J. Geol. 109, 155-170.

McLennan, S.M., 1989. Rare earth elements in sedimentary rocks: Influence of provenance and sedimentary processes. In: Lipin, B.R., McKay, G.A. (Eds.), Geochemistry and Mineralogy of Rare Earth Elements. Reviews in Mineralogy 21, 169-200.

Meybeck, M., 2003. Global occurrence of major elements in rivers. In: Drever, J.I. (Ed.), Geochemistry of Earth Surface Systems. Elsevier, Amsterdam. Treatise on Geochemistry 5, pp. 207-223.

Milliman, J.D., Meade, R.H., 1983. World-wide delivery of river sediments to ocean. J. Geol. 91, 1-19.

Milliman, J.D., Syvitski, J.P.M., 1992. Geomorphic/tectonic control of sediment transport to the ocean: the importance of small mountainous rivers. J. Geol. 100, 525-544.

Murad, E., Cashion, J., 2004. Mössbauer Spectroscopy of Environmental Materials and Industrial Utilization. Kluwer Academic Publisher, Boston.

Murad, E., Johnston, J.H., 1987. Iron oxides and oxyhydroxides. In: Long, G.L. (Ed.), Mössbauer Spectroscopy, Applied to Inorganic Chemistry. Plenum Press, New York. pp. 507-574. 
Peel, K., 2009. Studies into the stable isotope geochemistry of copper and zinc in aquatic systems. Ph. D. thesis, Imperial College London.

Peel, K., Weiss, D.J., Sigg, L., 2009. Zinc isotope composition of settling particles as a proxy for biogeochemical processes in lakes: Insights from the eutrophic Lake Greifen, Switzerland. Limnol. Oceanogr. 54, 1699-1708.

Piepgras, D.J., Wasserburg, G.J., 1980. Neodymium isotopic variations in seawater. Earth Planet. Sci. Lett. 50, $128-138$

Pin, C., Zalduegui, J.F.S., 1997. Sequential separation of light rare earth elements, thorium and uranium by miniaturized extraction chromatography: application to isotopic analyses of silicate rocks. Anal. Chim. Acta $339,79-89$

Poitrasson, F., 2006. On the iron isotope homogeneity level of the continental crust. Chem. Geol. 235, 195-200.

Pons, M.-L., Quitté, G., Fujii, T., Rosing, M.T., Reynard, B., Moynier, F., Douchet, C., Albarède, F., 2011. Early Archean serpentine mud volcanoes at Isua, Greenland, as a nich for early life. PNAS 108, 17639-17643.

Rouxel, O., Sholkovitz, E., Charette, M., Edwards, K.J., 2008. Iron isotope fractionation in subterranean estuaries. Geochim. Cosmochim. Acta 72, 3413-3430.

Schiltz, M., Vandenberghe, N., Gullentops, F., 1993. Toelichting bij de Geologische kaart van België, Vlaams Gewest, Kaartblad 16, Lier. Schaal 1: 50000. Technical Report, Belgische Geologische Dienst, Bestuur Natuurlijke Rijkdommen en Energie, pp. 56.

Sholkovitz, E.R., Copland, D., 1981. The coagulation, solubility and adsorption properties of Fe, Mn, Cu, Ni, Cd, Co and humic acids in a river water. Geochim. Cosmochim. Acta 45, 181-189.

Sonke, J.E., Hoogewerff, J.A., van der Laan, S.R., Vangronsveld, J., 2002. A chemical and mineralogical reconstruction of $\mathrm{Zn}$-smelter emissions in the Kempen region (Belgium), based on organic pool sediment cores. Sci. Total Environ. 292, 101-119.

Spring, S., 2006. The Genera Leptothrix and Sphaerotilus. In: Dworkin, M., Falkow, S., Rosenberg, E., Schleifer, K., Stackebrandt, E. (Eds.), The Prokaryotes. Springer, New York.

Stevens, J.G., Pollak, H., Yhe, L., Stevens, V.E., White, R., Gibson, J.L., 1983. Mineral Data. Mössbauer Effect Data Center, Asheville, pp. 103-104.

Sun, S.-S., McDonough, W.F., 1989. Chemical and isotopic systematics of oceanic basalts: implications for mantle composition and processes. In: Saunders, A.D., Norry, M.J. (Eds.), Magmatism in the Ocean Basins. Geological Society of London, Special Publications, 42, 313-345. 
Syvitski, J.P.M., Vörösmarty, C.J., Kettner, A.J., Green, P., 2005. Impact of humans on the flux of terrestrial sediment to the global coastal ocean. Science 308, 376-380.

Teutsch, N., von Gunten, U., Porcelli, D., Cirpka, O.A., Halliday, A.N., 2005. Adsorption as a cause for iron isotope fractionation in reduced groundwater. Geochim. Cosmochim. Acta 69, 4175-4185.

Vanlierde, E., De Schutter, J., Jacobs, P., Mostaert, F., 2007. Estimating and modeling the annual contribution of authigenic sediment to the total suspended sediment load in the Kleine Nete Basin, Belgium. Sediment. Geol. 202, 317-332.

Walling, D.E., Webb, B.W., 1996. Erosion and sediment yield: a global overview. Erosion and Sediment Yield: Global and Regional Perspectives, Proceedings of the Exeter Symposium. IAHS Publ. 236, pp. 3-19.

Walling, D.E., Fang, D., 2003. Recent trends in the suspended sediment loads of the world's rivers. Global Planet. Change 39, 111-126.

Warren, L.A., Zimmerman, A.P., 1994. Suspended particulate oxides and organic matter interactions in trace metal sorption reactions in a small urban river. Biogeochemistry 23, 21-34.

Weiss, D.J., Rausch, N., Mason, T.F.D., Coles, B.J., Wilkinson, J.J., Ukonmaanaho, L., Arnold, A., Nieminen, T.M., 2007. Atmospheric deposition and isotope biogeochemistry of zinc in ombrotrophic peat. Geochim. Cosmochim. Acta 71, 3498-3517.

Weiss, D.J., Boye, K., Caldelas, C., Fendorf, S., 2014. Zinc isotope fractionation during early dissolution of biotite granite. Soil Sci. Soc. Am. J. 78, 171-179.

Welch, S.A., Beard, B.L., Johnson, C.M., Braterman, P.S., 2003. Kinetic and equilibrium Fe isotope fractionation between aqueous Fe(II) and Fe(III). Geochim. Cosmochim. Acta 67, 4231-4250.

Wu, L., Beard, B.L., Roden, E.E., Johnson, C.M., 2011. Stable iron isotope fractionation between aqueous Fe(II) and hydrous ferric oxide. Environ. Sci. Technol. 45, 1847-1852. 


\section{Figure captions}

Fig. 1. Map of the Nete and Demer river basins (Belgium) with the sampling site location and cross-section (shown on Fig. 2). Some of the samples were taken from small streams not indicated on the map because they were out of the scale. Small black arrows indicate the locations where the photos A and B presented at Figure 3 A and B (respectively) were taken. Inset map (upper-right corner) shows the location of study area (rectangle) in Belgium.

Fig. 2. Geological cross-section through the Nete basin (Fig. 1) (modified from Vanlierde et al., 2007).

Fig. 3. Photos of: (A) the Grote Laak River at the mouth in the Grote Nete containing reddish-brown suspended matter; (B) reddish-brown fluffy sediments on the bed of the upstream reaches of the Mangelbeek River. For locations of the photos, see Figure 1.

Fig. 4. (A) SEM micrograph [secondary electron image (SEI)] of hollow, tube-like structures encrusted with Feoxyhydroxides; (B) close-up of the tube-like structures encrusted with Fe-oxyhydroxides shown in (A) (SEM micrograph, SEI); (C) TEM micrograph (unstained thin section) showing fine Fe-oxyhydroxide particles aggregated around "holes" [cross sections of the tube-like structures shown at (A) and (B)] reminiscent of remnants of bacteria; (D) EDS spectrum of a tube-like structure. All images and EDS spectrum of red sediment sample (\#4).

Fig. 5. (a) Raman spectrum typical of the studied red sediments (sample \#4) showing the presence of ferrihydrite; (b) and (c) transformation of Raman spectrum caused by the laser beam heat showing the transition from ferrihydrite to hematite.

Fig. 6. ${ }^{57} \mathrm{Fe}$ Mössbauer spectra at (a) $293 \mathrm{~K}$, and (b) $80 \mathrm{~K}$ of red sediments (sample \#2c).

Fig. 7. Plot of Fe/Hf vs. $\mathrm{Ni}_{\text {sample }} / \mathrm{Ni}_{\text {background sediment }}$ ratios for the studied samples. Sample numbers as in Table 1 . 
Fig. 8. REE distribution patterns of the studied suspended matter and sediment samples normalized to $\mathrm{C} 1$ chondrite (Sun and McDonough, 1989) (A) and to background sediment (B). Sample numbers as in Table 1: red suspended matter (\#\#1, 2a, 3a), red sediment (\#\#2b, 2c, 3b, 4, 6a, 6b), background sediment (\#5), sand from Diest Formation (\#7), red precipitate from Pidpa WPC (\#8).

Fig. 9. Sr-Nd isotopic relationships of the samples from the Nete and Demer river basins. Reference data for seawater and industrial sources are from Faure and Mensing (2005), Piepgras and Wasserburg (1982), Geagea et al. (2008).

Fig. 10. $\mathrm{Pb}$ isotope data of the samples from the Nete and Demer river basins. The industrial $\mathrm{Pb}$ line is from Haack et al. (2002), ore data (crosses) from Dejonghe (1988), and the field for modern aerosols in the Benelux countries and Germany from de Vleeschouwer et al. (2007).

Fig. 11. Sr-isotope composition of the samples from the Nete and Demer river basins. (A) ${ }^{87} \mathrm{Sr} /{ }^{86} \mathrm{Sr}$ versus $\mathrm{Al} / \mathrm{Fe}$. $\mathrm{SW}=$ seawater (McArthur et al., 2001), CC = mean continental crust (Hofmann, 1997). (B) ${ }^{87} \mathrm{Sr} /{ }^{86} \mathrm{Sr}$ versus $\mathrm{Sr}$ content. Hypothetical mixing scenarios between a geogenic $(\mathrm{G})$ and marine $\left(\mathrm{M}_{1}\right.$ and $\left.\mathrm{M}_{2}\right)$ components following two hyperbolic functions. Sample \# are the same as in Table 1. See text for details. 


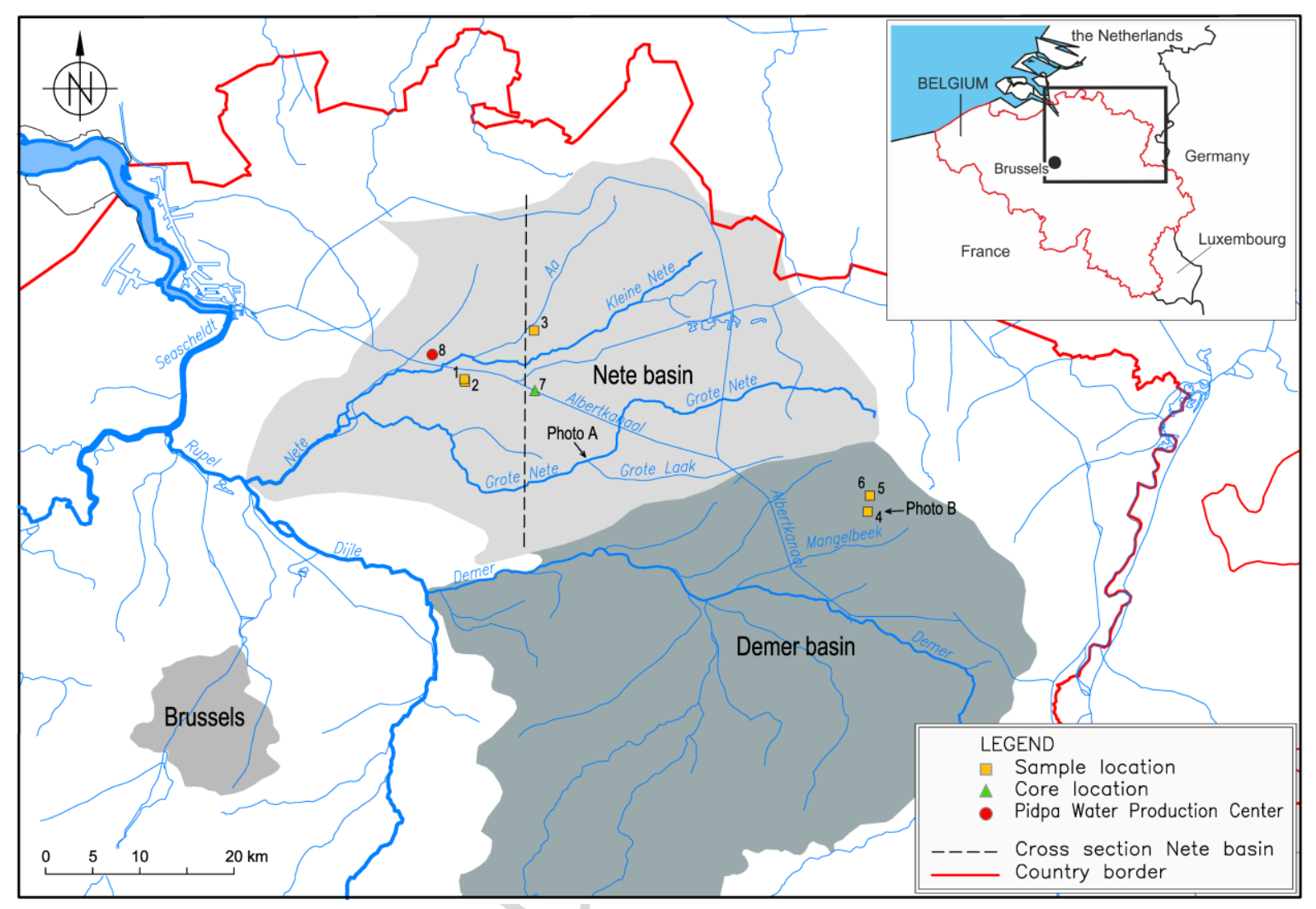

Figure 1 


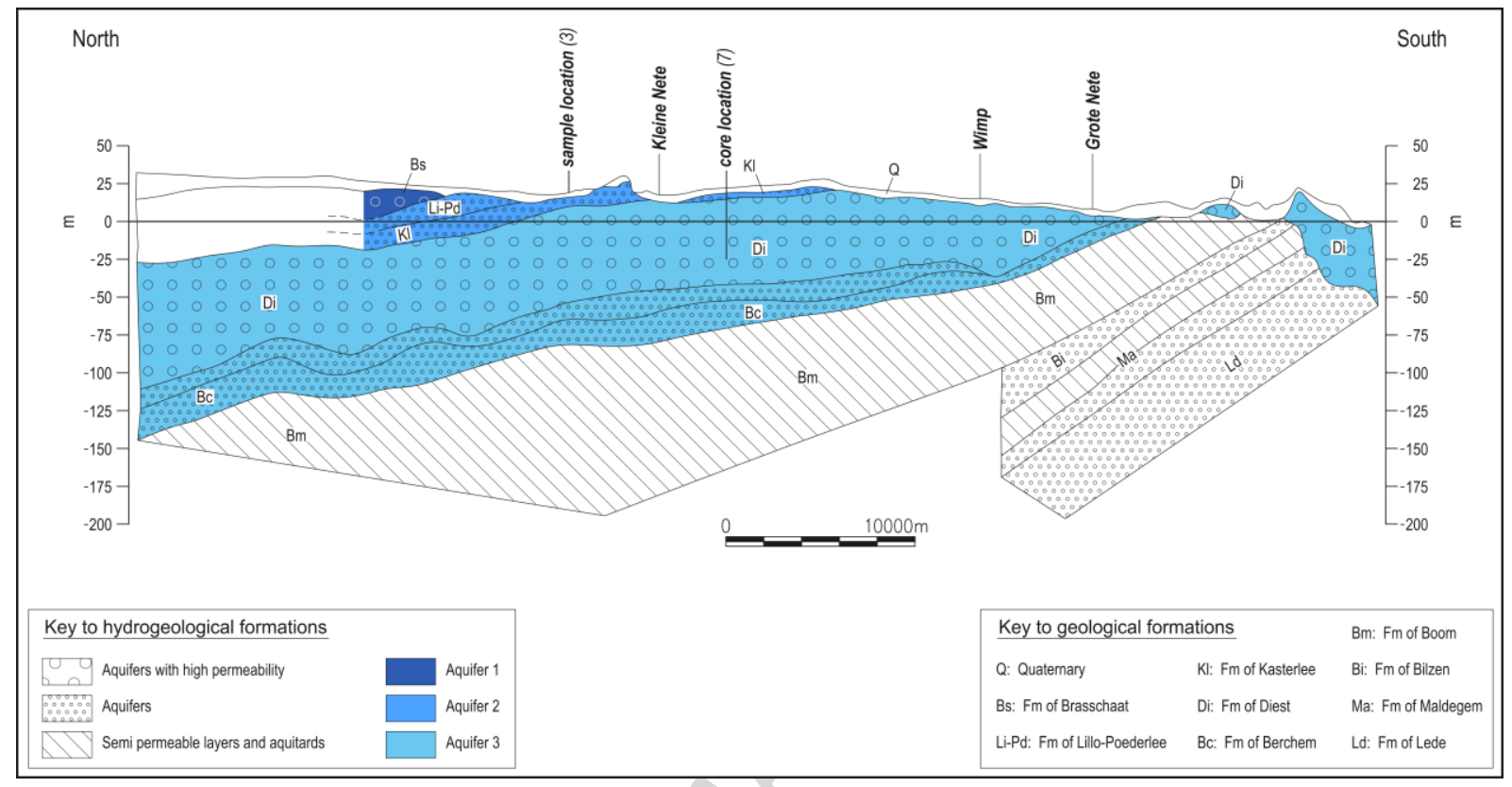

Figure 2 

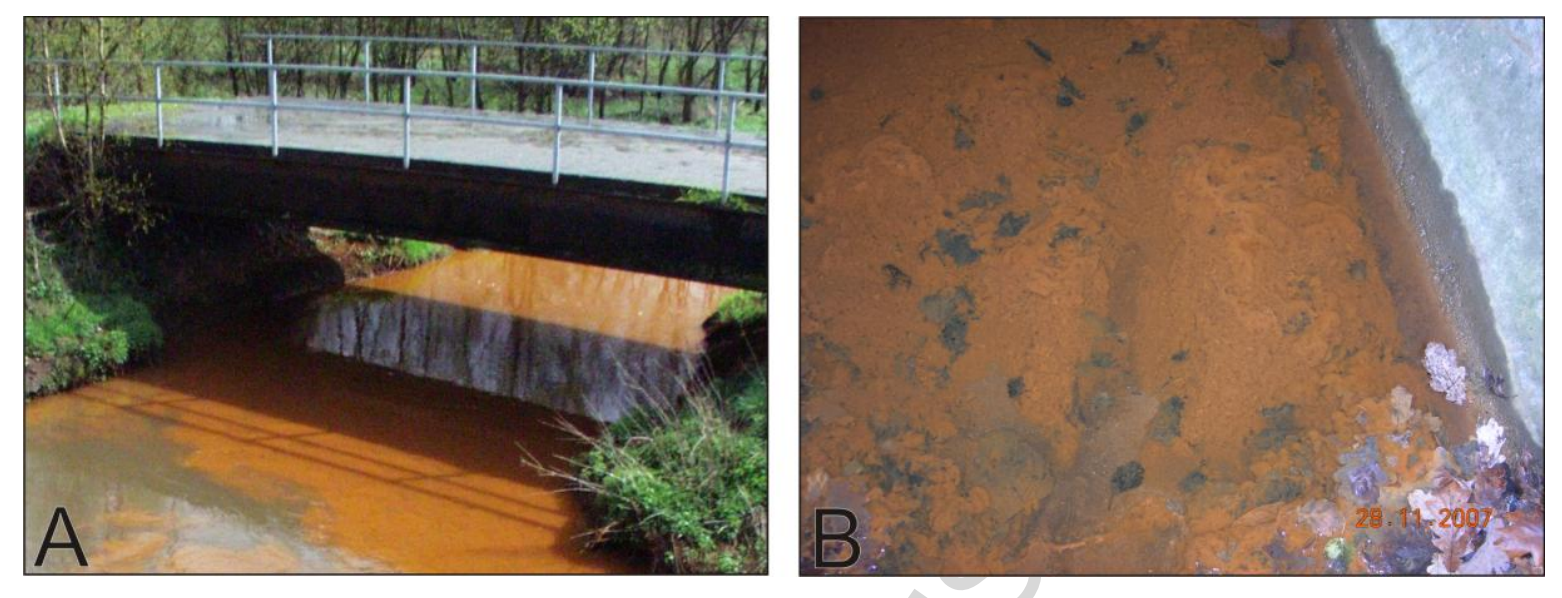

Figure 3 

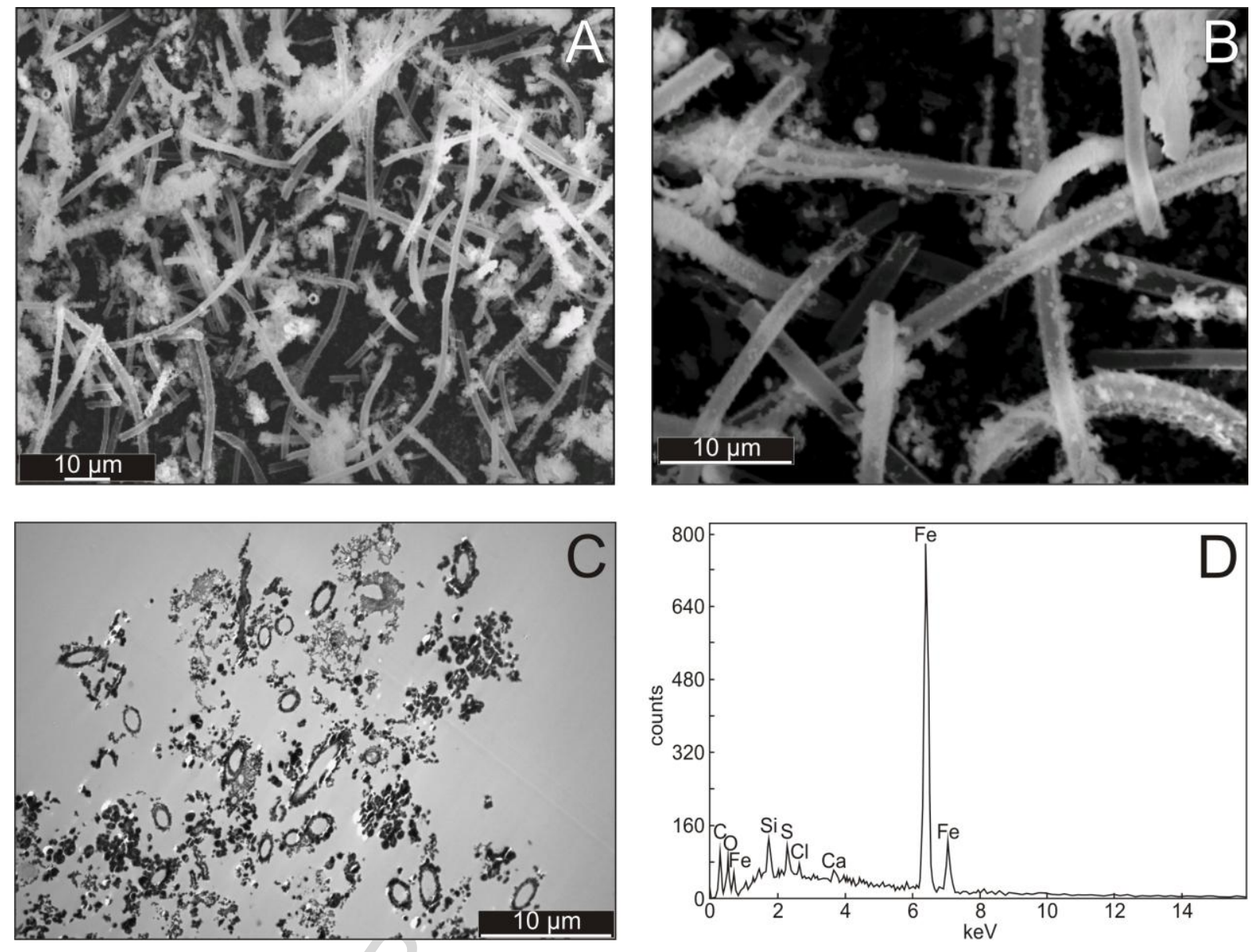

Figure 4 


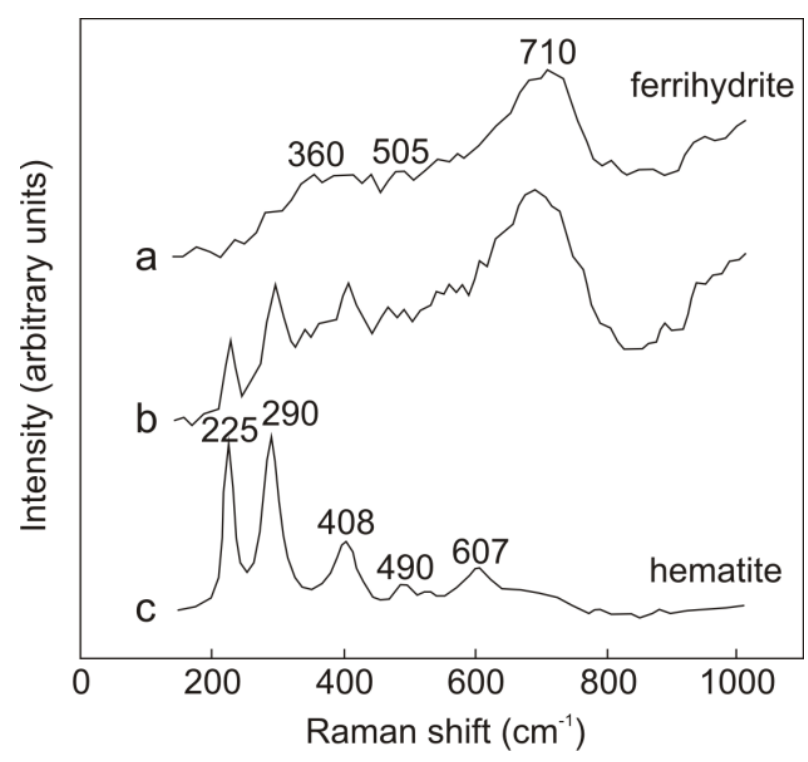

Figure 5 


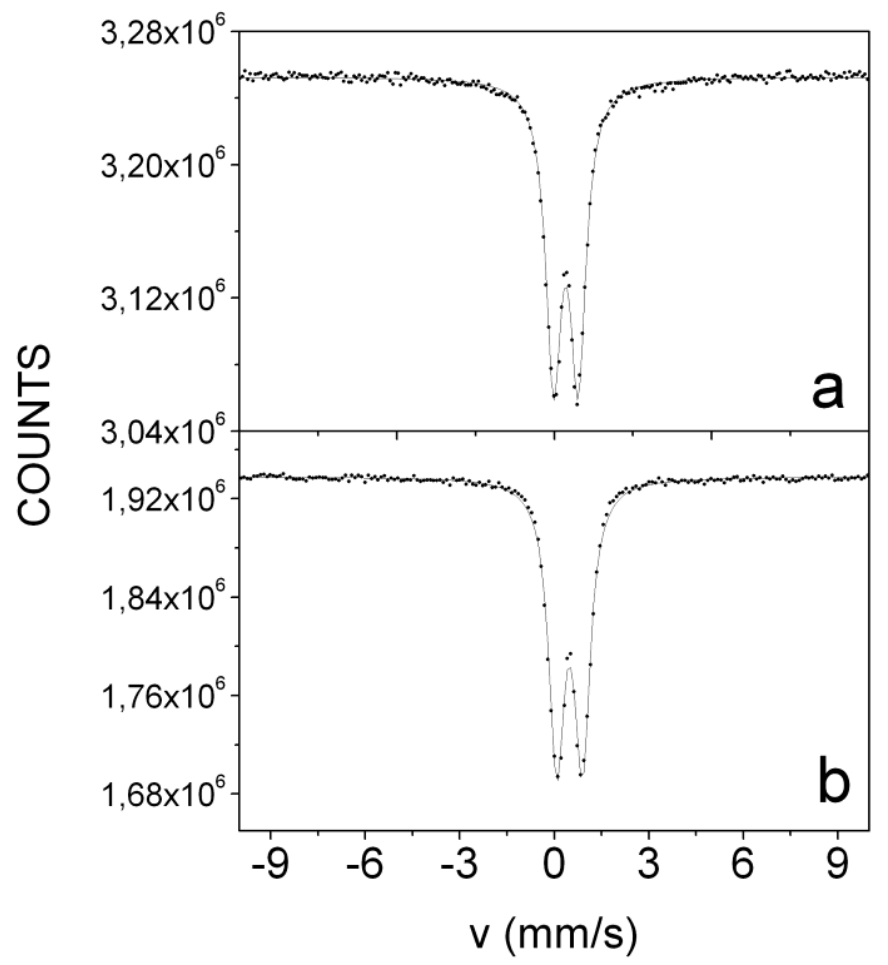

Figure 6 


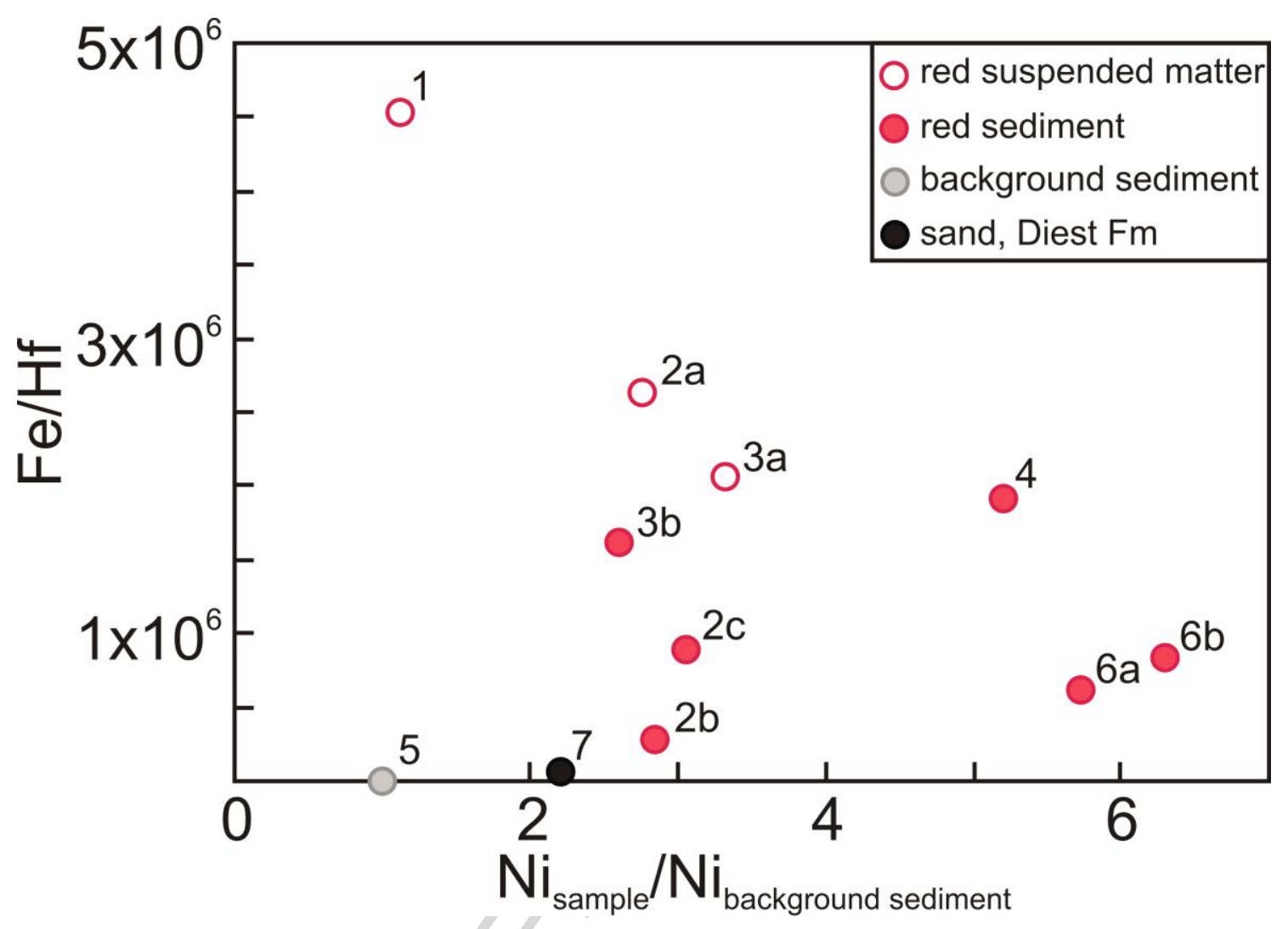

Figure 7 

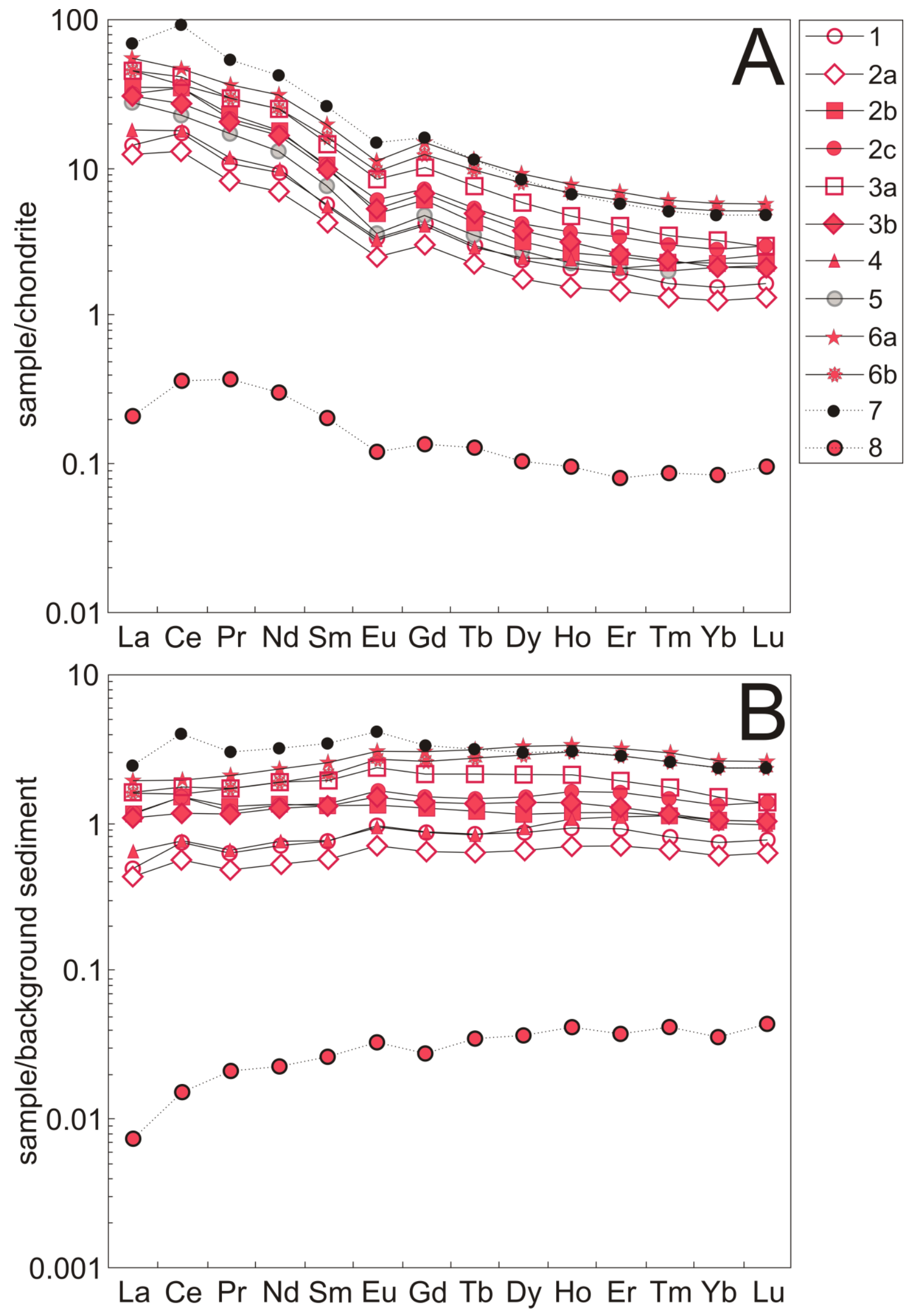

Figure 8 


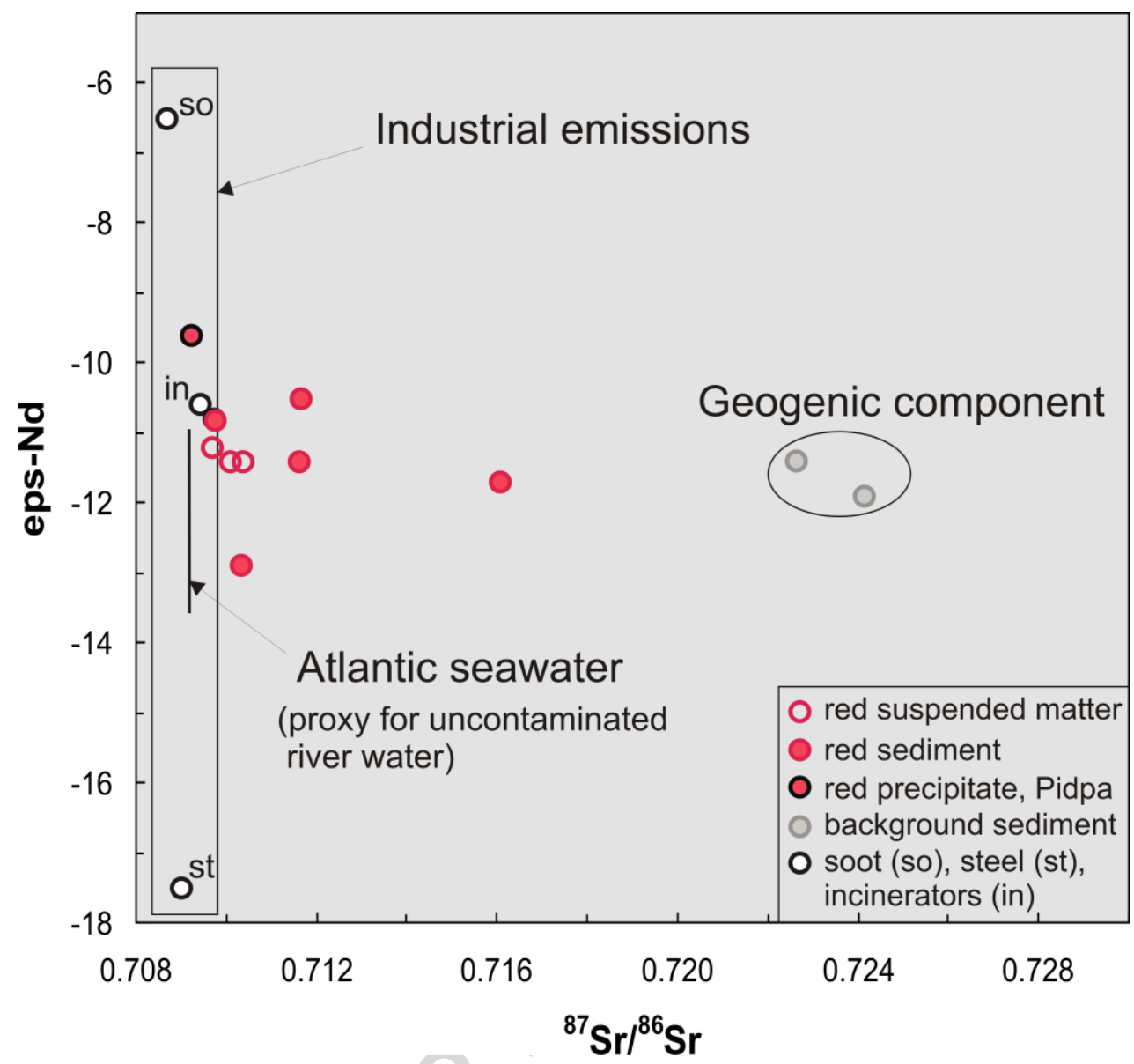

Figure 9 


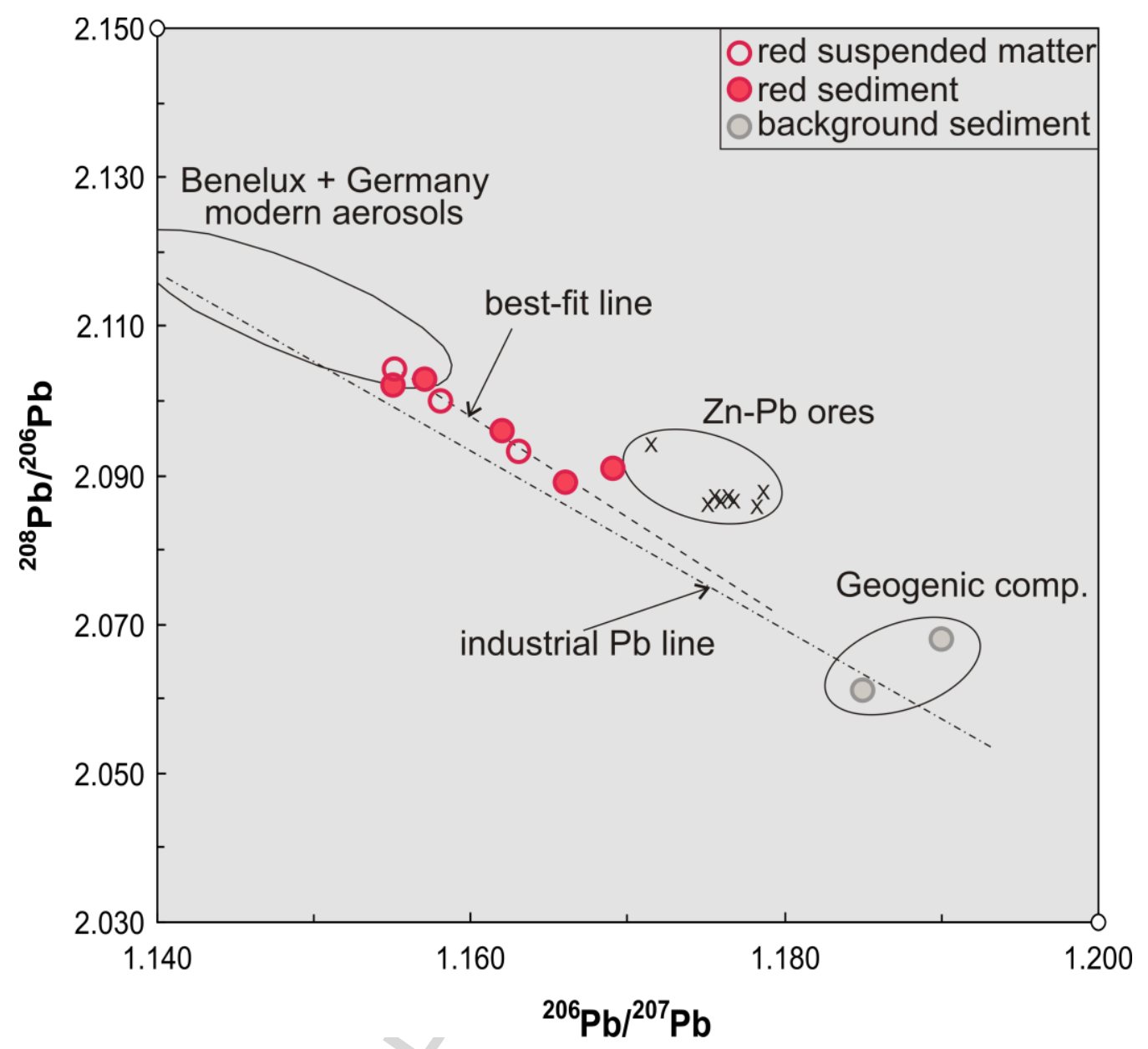

Figure 10 

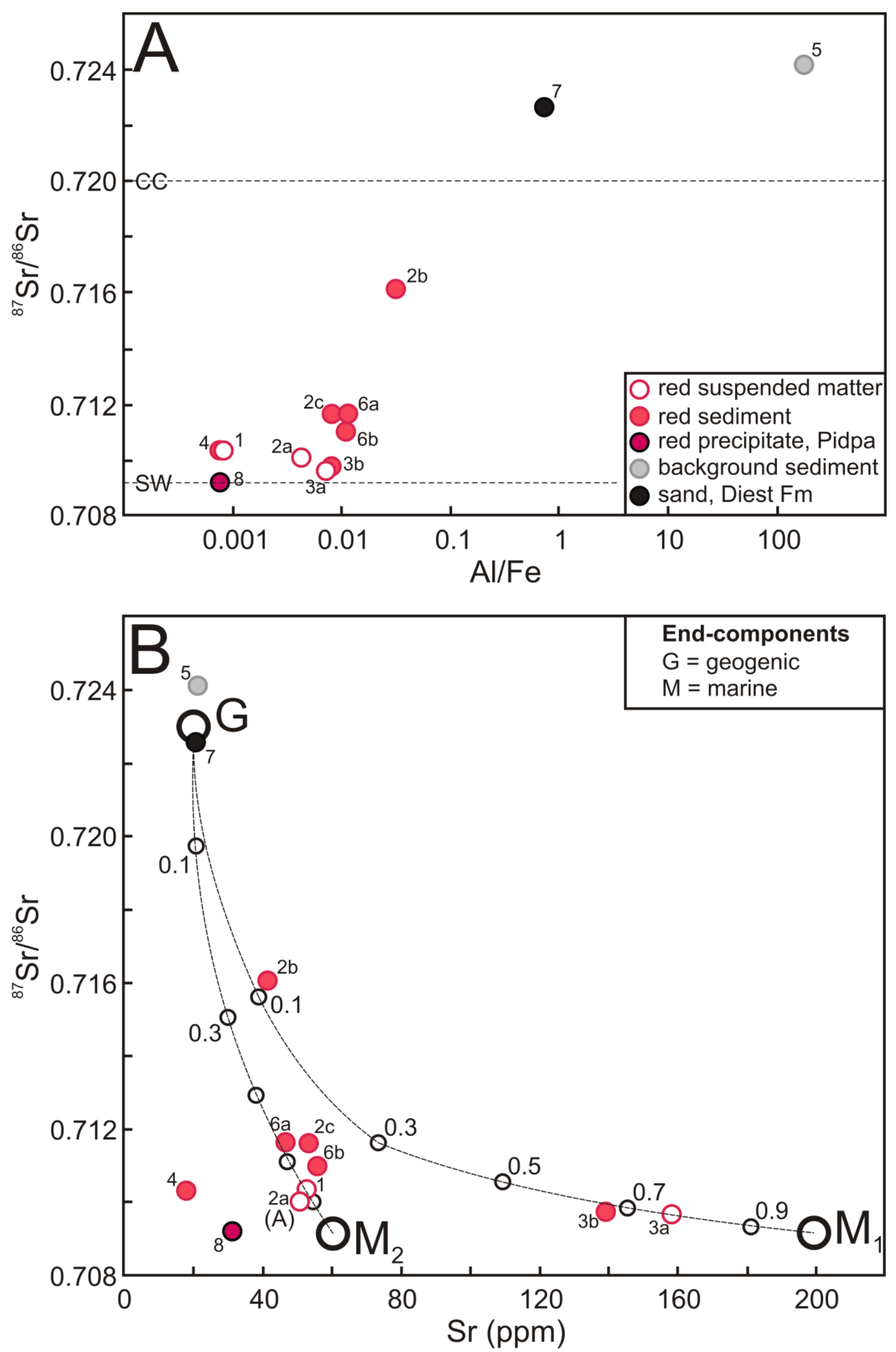

Figure 11. 
Table 1

Investigated suspended matter and sediment samples ${ }^{1}$, their mineralogy (from the MRS, XRD and Mössbauer spectroscopy) and river water parameters of the Nete and Demer river basins.

\begin{tabular}{|c|c|c|c|c|c|c|c|c|}
\hline Sample \# & Sample type & Sample location & $\begin{array}{l}\text { Latitude } \\
\text { (N) }\end{array}$ & $\begin{array}{l}\text { Longitude } \\
\text { (E) }\end{array}$ & Dominant mineralogy & $\begin{array}{l}\mathrm{T} \\
\left({ }^{\circ} \mathrm{C}\right)\end{array}$ & $\mathrm{pH}$ & $\begin{array}{l}\text { Eh } \\
(\mathrm{mV})\end{array}$ \\
\hline 1 & red suspended matter & Nieuwendijk, Bouwel & $51^{\circ} 10^{\prime} 14.853^{\prime \prime}$ & $4^{\circ} 45^{\prime} 14.260^{\prime \prime}$ & ferrihydrite & 14.45 & 6.75 & 133 \\
\hline $2 a$ & $-“-$ & Nieuwendijk, Bouwelgoorbeek & $51^{\circ} 10^{\prime} 5.871^{\prime \prime}$ & $4^{\circ} 45^{\prime} 17.817^{\prime \prime}$ & ferrihydrite, & 15.3 & $6.71-7.04$ & 272.4 \\
\hline $2 b$ & red sediment & Nieuwendijk, Bouwelgoorbeek & $51^{\circ} 10^{\prime} 5.560^{\prime \prime}$ & $4^{\circ} 45^{\prime} 16.449^{\prime \prime}$ & ferrihydrite, quartz & & & \\
\hline $2 c$ & $-“-$ & Nieuwendijk, Bouwelgoorbeek & $51^{\circ} 10^{\prime} 5.287^{\prime \prime}$ & $4^{\circ} 45^{\prime} 17.022^{\prime \prime}$ & ferrihydrite, quartz & & & \\
\hline $3 a$ & red suspended matter & Lichtaartsesteenweg, Poederlee & $51^{\circ} 13^{\prime} 0.159^{\prime \prime}$ & $4^{\circ} 51^{\prime} 36.628^{\prime \prime}$ & ferrihydrite & 15.94 & 7.11 & 294 \\
\hline $3 b$ & red sediment & $-"-$ & $-“-$ & - “ - & ferrihydrite, quartz & & & \\
\hline 4 & $-“-$ & Europarklaan, Houthalen Helchteren & $51^{\circ} 2 ' 26.944^{\prime \prime}$ & $5^{\circ} 21^{\prime} 46.578^{\prime \prime}$ & ferrihydrite, quartz & 14.36 & 6.53 & 233.9 \\
\hline 5 & background sediment & Loerstraat, Houthalen Helchteren & $51^{\circ} 3^{\prime} 21.633^{\prime \prime}$ & $5^{\circ} 22^{\prime} 0.265^{\prime \prime}$ & quartz & 18.43 & 7.66 & 345 \\
\hline $6 a$ & red sediment & $\begin{array}{l}\text { Loerstraat, Houthalen Helchteren, 2nd } \\
\text { river }\end{array}$ & $51^{\circ} 3^{\prime} 22.899^{\prime \prime}$ & $5^{\circ} 21^{\prime} 58.228^{\prime \prime}$ & ferrihydrite, quartz & 16.33 & 6.78 & 303.5 \\
\hline $6 b$ & $-“-$ & $-“-$ & $-“-$ & - “ - & ferrihydrite, quartz & 16.16 & 7.27 & 337.3 \\
\hline 7 & sand from Diest Formation & Sluis Olen, \#II-4 & $51^{\circ} 9^{\prime} 30.00^{\prime \prime}$ & $4^{\circ} 51^{\prime} 39.00^{\prime \prime}$ & quartz, glauconite & & & \\
\hline $7 a$ & $\begin{array}{l}\text { electromagnetic fraction of sand from } \\
\text { Diest Formation }\end{array}$ & $-“-$ & -“ - & $-“-$ & glauconite & & & \\
\hline 8 & red precipitate & WPC Grobbendonk, Pidpa & & & ferrihydrite & & & \\
\hline
\end{tabular}

${ }^{1}$ All samples collected on 07.06.2010. 


\section{Table 2}

Mössbauer parameters of the samples from the Nete and Demer river basins.

\begin{tabular}{|c|c|c|c|c|c|}
\hline Sample \# & Sample type & $\begin{array}{l}\delta^{1} \\
(\mathrm{~mm} / \mathrm{s})\end{array}$ & $\begin{array}{l}\Delta^{1} \\
(\mathrm{~mm} / \mathrm{s})\end{array}$ & $\begin{array}{l}\delta^{2} \\
(\mathrm{~mm} / \mathrm{s})\end{array}$ & $\begin{array}{l}\Delta^{2} \\
(\mathrm{~mm} / \mathrm{s})\end{array}$ \\
\hline 1 & red suspended matter & 0.37 & 0.82 & 0.48 & 0.88 \\
\hline $2 a$ & $-"$ - & 0.37 & 0.82 & 0.48 & 0.82 \\
\hline $2 b$ & red sediment & 0.37 & 0.74 & 0.48 & 0.79 \\
\hline $2 c$ & $-“-$ & 0.36 & 0.78 & 0.48 & 0.87 \\
\hline $3 a$ & red suspended matter & 0.36 & 0.77 & 0.47 & 0.82 \\
\hline $3 b$ & red sediment & 0.37 & 0.74 & 0.47 & 0.82 \\
\hline $6 a$ & $-"$ - & 0.37 & 0.75 & 0.47 & 0.82 \\
\hline $6 b$ & $-"$ - & 0.37 & 0.77 & 0.47 & 0.78 \\
\hline 8 & red precipitate, Pidpa & 0.36 & 0.82 & 0.47 & 0.82 \\
\hline
\end{tabular}

${ }^{1}$ At 293K.

${ }^{2}$ At $80 \mathrm{~K}$. 
Table 3

Chemical composition (XRF and ICP-MS) of the samples from the Nete and Demer river basins.

\begin{tabular}{|c|c|c|c|c|c|c|c|c|c|c|c|c|c|c|c|c|c|c|c|c|c|c|c|c|c|c|}
\hline Sample \# & $\begin{array}{l}\text { Sample } \\
\text { type }\end{array}$ & $\begin{array}{l}\mathrm{Si} \\
\text { (wt: } \%)\end{array}$ & Al & $\mathrm{Fe}$ & Mn & P & $\mathrm{s}$ & $\mathrm{Ca}$ & $\mathrm{K}$ & $\mathrm{Ti}$ & $\mathrm{Cl}$ & $\begin{array}{l}\text { As } \\
\text { (ppm) }\end{array}$ & $\mathrm{Nb}$ & Li & Sc & $\mathrm{v}$ & $\mathrm{Cr}$ & Co & $\mathrm{Ni}$ & $\begin{array}{l}\text { Cu } \\
\text { (ppm) }\end{array}$ & $\mathrm{Zn}$ & $\mathrm{Rb}$ & $\mathrm{Sr}$ & $\mathrm{Y}$ & $\mathrm{Zr}$ & Mo \\
\hline 1 & $\begin{array}{l}\text { red } \\
\text { suspended } \\
\text { matter }\end{array}$ & 1.19 & $<0.03$ & 36.2 & 0.03 & 2.21 & 0.44 & 0.37 & $<0.01$ & 0.07 & 0.17 & 18.7 & 3.02 & 0.37 & 0.37 & 22,6 & 78.9 & $<1$ & 2.55 & 15.9 & 31.3 & 2.02 & 52.5 & 3.82 & $<1$ & 0.84 \\
\hline 2a & -" - & 1.33 & 0.15 & 34.1 & 0.03 & 0.49 & 0.53 & 1.80 & 0.01 & 0.07 & 0.25 & 17.5 & $<2$ & 1.69 & 0.42 & 12.3 & 29.1 & 2.80 & 6.26 & 15.4 & 47.2 & 3.68 & 50.5 & 2.99 & $<1$ & 3.01 \\
\hline $2 \mathrm{~b}$ & $\begin{array}{l}\text { red } \\
\text { sediment }\end{array}$ & 11.1 & 0.65 & 19.8 & 0.01 & 0.39 & 0.46 & 0.75 & 0.53 & 0.09 & 0.12 & 18.1 & $<2$ & 5.20 & 1.44 & 27.5 & 44,2 & 2.44 & 6.45 & 8.92 & 77.6 & 29.5 & 41.2 & 4.78 & 24.5 & 1.09 \\
\hline $2 \mathrm{c}$ & -" - & 2.17 & 0.27 & 31.8 & 0.01 & 0.82 & 0.51 & 1.11 & 0.04 & 0.08 & 0.15 & 19.7 & $<2$ & 2.04 & 0.83 & 25.9 & 44.7 & 2.32 & 6.94 & 15.8 & 102 & 9.65 & 53.1 & 7.00 & 9.75 & 1.77 \\
\hline $3 \mathrm{a}$ & $\begin{array}{l}\text { red } \\
\text { suspended }\end{array}$ & 3.11 & 0.26 & 35.0 & 0.02 & 1.01 & 0.36 & 2.04 & $<0.01$ & 0.08 & 0.10 & 20.9 & $<2$ & 1.92 & 0.81 & 15.7 & 12.0 & 2.93 & 7.53 & 20.8 & 182 & 5.33 & 158 & 8.58 & $<1$ & 2.43 \\
\hline 3b & $\begin{array}{l}\text { red } \\
\text { sediment }\end{array}$ & 2.96 & 0.27 & 33.9 & 0.01 & 0.78 & 0.45 & 2.09 & 0.03 & 0.08 & 0.19 & 23.1 & $<2$ & 2.46 & 0.73 & 14.0 & 11.0 & 2.36 & 5.90 & 17.2 & 166 & 5.98 & 139 & 5.48 & 4.59 & 2.42 \\
\hline 4 & - " - & 2.27 & $<0.03$ & 38.1 & 0.01 & $<0.003$ & 0.43 & 0.10 & $<0.01$ & 0.07 & 0.14 & 31.2 & $<2$ & 0.57 & 0.88 & 20.7 & 17.4 & 8.18 & 11.8 & 2.16 & 76.3 & 1.46 & 17.6 & 4.81 & 4.09 & 4.77 \\
\hline 5 & $\begin{array}{l}\text { background } \\
\text { sediment }\end{array}$ & 45.9 & 1.24 & $<0.007$ & 0.01 & $<0.003$ & 0.24 & $<0.002$ & 0.27 & 0.14 & 0.08 & $<5$ & 6.32 & 5.79 & 0.84 & 10.7 & 14.9 & 0.62 & 2.27 & 3.47 & 52.1 & 16.1 & 21.0 & 3.64 & 37.9 & 0.14 \\
\hline 6a & $\begin{array}{l}\text { red } \\
\text { sediment }\end{array}$ & 2.94 & 0.38 & 32.6 & 0.03 & 0.15 & 0.57 & 1.34 & $<0.01$ & 0.09 & 0.13 & 29.4 & $<2$ & 2.30 & 1.11 & 63.7 & 29.1 & 3.22 & 13.0 & 12.4 & 126 & 6.17 & 46.4 & 14.7 & 18.4 & 1.67 \\
\hline $6 \mathrm{~b}$ & - " - & 3.36 & 0.36 & 32.4 & 0.13 & 0.13 & 0.84 & 1.94 & 0.01 & 0.08 & 0.26 & 27.3 & 4.17 & 2.55 & 0.98 & 57.3 & 24.1 & 7.09 & 14.3 & 13.7 & 126 & 5.77 & 55.6 & 13.1 & 11.4 & 1.64 \\
\hline 7 & $\begin{array}{l}\text { sand, Diest } \\
\text { Formation }\end{array}$ & 34.7 & 2.72 & 3.67 & $<0.01$ & $<0.003$ & 0.31 & $<0.002$ & 1.87 & 0.09 & $<0.007$ & 25.5 & 4.31 & 9.27 & 2.89 & 64.7 & 82.2 & 2.24 & 5.01 & 0.64 & 100 & 69.5 & 20.5 & 11.5 & 17.1 & 0.20 \\
\hline 8 & $\begin{array}{l}\text { red } \\
\text { precipitate, } \\
\text { Pidpa }\end{array}$ & 3.43 & $<0.03$ & 38.9 & $<0.01$ & 0.33 & 0.34 & $<0.002$ & $<0.01$ & 0.06 & 0.08 & 16.5 & $<2$ & $<1$ & $<1$ & $<5$ & $<5$ & $<1$ & $<1$ & $<1$ & $<5$ & $<1$ & 31.0 & $<0.5$ & $<1$ & $<1$ \\
\hline GSPN-2 $2^{a}$ & standard & - & - & - & - & - & - & - & - & - & - & - & - & 78.0 & 13.0 & 456 & 17.0 & 2900 & 10200 & 6900 & 918 & 16.0 & 875 & 144 & 614 & 473 \\
\hline GSPN- $2^{\mathrm{b}}$ & $-"=$ & - & - & - & - & - & - & - & - & - & - & - & - & 75.9 & 14.6 & 497 & 12.9 & 2891 & 10062 & 6699 & 910 & 16.8 & 918 & 146 & 644 & 477 \\
\hline
\end{tabular}

${ }^{2}$ Reference data.

Data from this study.

$\mathrm{Ce} / \mathrm{Ce}^{\mathrm{r}}=2 \mathrm{Ce}_{\mathrm{N}}\left(\mathrm{La}_{\mathrm{N}}+\mathrm{Pr}_{\mathrm{N}}\right)$.

$\mathrm{Eu}^{\mathrm{E}} \mathrm{Eu}^{*}=2 \mathrm{Eu}_{N} /\left(\mathrm{Sm}_{\mathrm{N}}+\mathrm{Gd}_{\mathrm{N}}\right)$ 
Table 4

Isotopic compositions of the samples from the Nete and Demer river basins.

\begin{tabular}{|c|c|c|c|c|c|c|c|c|c|c|}
\hline Sample \# & Sample type & ${ }^{87} \mathrm{Sr} /{ }^{86} \mathrm{Sr}^{1}$ & ${ }^{143} \mathrm{Nd} /{ }^{144} \mathrm{Nd}^{1}$ & $\varepsilon-\mathrm{Nd}$ & ${ }^{206} \mathrm{~Pb} /{ }^{204} \mathrm{~Pb}$ & ${ }^{206} \mathrm{~Pb} /{ }^{207} \mathrm{~Pb}$ & ${ }^{208} \mathrm{~Pb} /{ }^{206} \mathrm{~Pb}$ & $\begin{array}{l}\delta^{56} \mathrm{Fe} \\
(\% 0)\end{array}$ & $\begin{array}{l}\delta^{57} \mathrm{Fe} \\
(\% 0)\end{array}$ & $\begin{array}{l}\delta^{66} \mathrm{Zn} \\
(\% 0)\end{array}$ \\
\hline 1 & red suspended matter & $0.710364 \pm 12$ & $0.512055 \pm 5$ & -11.4 & 18.150 & 1.163 & 2.093 & $0.41 \pm 0.11$ & $0.62 \pm 0.17$ & $0.02 \pm 0.03$ \\
\hline $2 \mathrm{a}$ & $-“$ & $0.710034 \pm 13$ & $0.512052 \pm 6$ & -11.4 & 17.997 & 1.155 & 2.104 & - & - & \\
\hline $2 b$ & red sediment & $0.716068 \pm 14$ & $0.512037 \pm 8$ & -11.7 & 18.191 & 1.166 & 2.089 & $-0.31 \pm 0.10$ & $-0.43 \pm 0.17$ & $0.14 \pm 0.06$ \\
\hline $2 \mathrm{c}$ & $-“-$ & $0.711625 \pm 10$ & $0.512052 \pm 8$ & -11.4 & 18.000 & 1.155 & 2.102 & - & - & \\
\hline $3 a$ & red suspended matter & $0.709685 \pm 10$ & $0.512066 \pm 4$ & -11.2 & 18.070 & 1.158 & 2.100 & $0.38 \pm 0.08$ & $0.58 \pm 0.04$ & $0.03 \pm 0.07$ \\
\hline $3 b$ & red sediment & $0.709752 \pm 11$ & $0.512082 \pm 6$ & -10.8 & 18.112 & 1.162 & 2.096 & $0.63 \pm 0.05$ & $0.93 \pm 0.07$ & $0.40 \pm 0.02$ \\
\hline 4 & $-“-$ & $0.710328 \pm 12$ & $0.511977 \pm 6$ & -12.9 & 18.260 & 1.169 & 2.091 & - & - & \\
\hline $6 a$ & red sediment & $0.711651 \pm 10$ & $0.512099 \pm 3$ & -10.5 & 18.043 & 1.157 & 2.103 & - & - & \\
\hline $6 a-$ repetition $^{2}$ & - " & $0.711579 \pm 18$ & $0.512091 \pm 6$ & -10.7 & 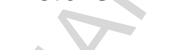 & & & - & - & \\
\hline $6 \mathrm{~b}$ & $-“-$ & $0.710997 \pm 11$ & $0.512106 \pm 5$ & -10.4 & 18.022 & 1.156 & 2.105 & - & - & \\
\hline 7 & sand, Diest Formation & $0.722598 \pm 08$ & $0.512055 \pm 5$ & -11.4 & 18.529 & 1.190 & 2.068 & $0.42 \pm 0.05$ & $0.65 \pm 0.09$ & $0.34 \pm 0.09$ \\
\hline 8 & red precipitate, Pidpa & $0.709220 \pm 13$ & $0.512146 \pm 36$ & -9.6 & & - & - & - & - & \\
\hline $8-$ repetition $^{2}$ & 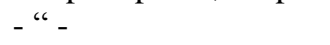 & $0.709717 \pm 20$ & $0.512083 \pm 8$ & -10.8 & - & - & - & - & - & \\
\hline
\end{tabular}

${ }^{\mathbf{1}}$ Errors affecting the last decimals are given as $2 \sigma_{\mathrm{m}}$ values.

${ }^{2}$ Duplicate samples involved grinded bulk sample \#6a, whereas separate granules were used when digesting sample \#8. 